\title{
Causality assessment of adverse events following
}

\section{immunization: the problem of multifactorial pathology}

\section{[version 1; peer review: 1 approved, 2 approved with}

\section{reservations, 1 not approved]}

\author{
Paolo Bellavite (iD \\ Department of Medicine, Section of General Pathology, University of Verona Medical School, Verona, 37134, Italy
}

V1 First published: 09 Mar 2020, 9:170
https://doi.org/10.12688/f1000research.22600.1
Latest published: 14 Apr 2020, 9:170

https://doi.org/10.12688/f1000research.22600.2

\section{Abstract}

The analysis of Adverse Events Following Immunization (AEFI) is important in a balanced epidemiological evaluation of vaccines and in the issues related to national vaccine injury compensation programs. If manufacturing defects or vaccine storage and delivering errors are excluded, the majority of adverse reactions to vaccines occur as excessive or biased inflammatory and immune responses. These unwanted phenomena, occasionally severe, are associated with many different endogenous and exogenous factors, which often interact in complex ways. The confirmation or denial of the causal link between an AEFI and vaccination is determined pursuant to WHO guidelines, which propose a four-step analysis and algorithmic diagramming. The evaluation process from the onset considers all possible "other causes" that can explain the AEFI and thus exclude the role of the vaccine. Subsequently, even if there was biological plausibility and temporal compatibility for a causal association between the vaccine and the AEFI, the guidelines ask to look for any possible evidence that the vaccine could not have caused that event. Such an algorithmic method presents some concerns that are discussed here, in the light of the multifactorial nature of the inflammatory and immune pathologies induced by vaccines, including emerging knowledge of genetic susceptibility to adverse effects. It is proposed that the causality assessment could exclude a consistent association of the adverse event with the vaccine only when the presumed "other cause" is independent of an interaction with the vaccine. Furthermore, the scientific literature should be viewed not as an exclusion criterion but as a comprehensive analysis of all the evidence for or against the role of the vaccine in causing an adverse reaction. These issues are discussed in relation to the laws that, in some countries, regulate the mandatory vaccinations and the compensation for those who have suffered serious adverse effects.

\author{
Open Peer Review \\ Approval Status $\checkmark \checkmark$

$\begin{array}{llll}1 & 2 & 3 & 4\end{array}$ \\ version 2 \\ (revision) \\ 14 Apr 2020 \\ version 1 \\ 09 Mar 2020

$\begin{array}{llc}2 & 3 & 4\end{array}$ \\ 1. David Legge (iD), La Trobe University, \\ Melbourne, Australia \\ 2. Jacob Puliyel iD, Holy Family Hospital, New \\ Delhi, India \\ 3. Christopher Exley (iD), Keele University, \\ Keele, UK \\ 4. Rebecca Chandler ID, Uppsala Monitoring \\ Centre, Uppsala, Sweden
}

Any reports and responses or comments on the article can be found at the end of the article. 


\section{Keywords}

Vaccination, Adverse events following immunization, Inflammation, Autoimmunity, Genetic susceptibility, Multifactorial diseases, Mandatory vaccinations, Injury compensation

Corresponding author: Paolo Bellavite (paolo.bellavite@univr.it)

Author roles: Bellavite P: Writing - Review \& Editing

Competing interests: The author has no competing interests. In the past three years he has been involved in some consultancy, conferences and publications in which he has supported the freedom of vaccination. He has always carried out these activities for free and in none of these activities has he received any payment, direct or indirect. In particular, the author wrote a "pro-veritate" memorandum in defence of a doctor in a disciplinary procedure activated by Treviso (I) medical Order to contest positions contrary to indiscriminate vaccinations; advised the Veneto Region on the occasion of the appeal to the Italian Constitutional Court against Law 119/2017; wrote a document on invitation to the Senate Hygiene and Health Commission advocating the cause of vaccination freedom; and recently studied the case of a girl affected by post-vaccination encephalopathy in the request for compensation ex-law $210 / 1992$. The proceeds of his book "Vaccines yes, Obligations no" (Libreria Cortina Editions, Verona, 2017) is entirely donated to a charity association. He does not profit financially in any way from the scientific work on the subject of this article.

Grant information: The author declared that no grants were involved in supporting this work. Article processing charges were supported by Condav, a not-for-profit charity based in Mantova, Italy.

The funders had no role in study design, data collection and analysis, decision to publish, or preparation of the manuscript.

Copyright: (c) 2020 Bellavite P. This is an open access article distributed under the terms of the Creative Commons Attribution License, which permits unrestricted use, distribution, and reproduction in any medium, provided the original work is properly cited.

How to cite this article: Bellavite P. Causality assessment of adverse events following immunization: the problem of multifactorial pathology [version 1; peer review: 1 approved, 2 approved with reservations, 1 not approved] F1000Research 2020, 9:170 https://doi.org/10.12688/f1000research.22600.1

First published: 09 Mar 2020, 9:170 https://doi.org/10.12688/f1000research.22600.1 


\section{Introduction}

Public health policy supports broad vaccination and, at the same time, acknowledges the prospect of adverse events following immunization (AEFI), harming a few "unlucky" individuals. Most countries have introduced laws that allow compensation for people who think they have been seriously and/or permanently damaged by recommended or mandatory vaccines, or for families in case of death. An AEFI is defined as "any untoward medical occurrence which follows immunization and which does not necessarily have a causal relationship with the administration of the vaccine. The adverse event may be any unfavorable or unintended indication, abnormal laboratory finding, a symptom or a disease." . Although the rules introduced by different countries often diverge ${ }^{2-4}$, an essential part of the evaluation of AEFI is the search for whether or not there is a causal link between the administered vaccine and the subsequent pathological phenomenon. It is evident that in this area, the causality assessment plays a crucial role for both public health policies and any possibly injured individuals.

WHO guidelines for causality assessment ${ }^{1}$, provide that "Allegations that vaccines/vaccination causes adverse events must be dealt with rapidly and effectively. Failure to do so can undermine confidence in a vaccine and ultimately have dramatic consequences for immunization coverage and disease incidence long after proof is generated that the adverse event was not caused by a vaccine (e.g. autism and MMR, encephalopathy and pertussis)." This articulation is entirely understandable and plausible. The same guidelines do not mention the affected individual for whom a causal inquiry is important, as in the absence of damage causation recognition, the harmed individual cannot access any compensation by provided programs. In addition to generating an obvious injustice, too rigid and restrictive rules could undermine the confidence of the population in the vaccine solution, create an expectation of claim denial and lead paradoxically to a decline in coverage. Present trends in several countries towards an increasing number of mandatory vaccines, is a delicate and controversial subject, impacting both social and economic concerns ${ }^{5}$. This is another reason why it is important that the procedure of causality assessment is accurate in theory and practice.

Causality is the relationship between two events (the cause and effect), wherein the second event is a consequence of the first. The WHO guidelines" acknowledge that "Sometimes there are multiple factors that may precipitate the effect (event) or may function as co-factors so the side effect (event) occurs." As far as vaccines are concerned, the fact that severe reactions affect only a few individuals suggests in most cases vaccines are not the only cause of the event and further factors are necessary in the development of pathology.

The growth of multifactorial diseases in the last decades has led to the development of the "medicine of complexity", ranging from cardiology $y^{7}$ to epidemiology $y^{8,9}$, from pharmacology $y^{10}$ to nursing care $^{11}$, or forensic medicine ${ }^{12}$. To underline the importance of the topic in modern medicine, in 2002 the journal Science dedicated a whole issue (vol. 296, n. 5568) to the "puzzle of complex diseases", including papers on the causes of diabetes ${ }^{13}$, systemic lupus erythematosus (SLE) $)^{14}$, schizophrenia ${ }^{15}$, and considering the challenges of sorting out the multiple genetic, infectious and life-style factors and their interaction in the pathogenesis of common diseases. The pathogenesis of autoimmune disease is characterized by a complex interaction between genetic and environmental factors, and immune and hormonal reactions, which is the much talked of "mosaic of autoimmunity" ${ }^{16}$. In vaccinology, the new developing fields of "vaccinomics" and "adversomics" exploit the powerful tools of bioinformatics to study adverse side effects to vaccines, using a systems biology approach ${ }^{17-22}$. Furthermore, disorders characterized by episodes of exaggerated inflammatory response "hyperinflammatory states" or "autoinflammatory syndromes" develop as multifactorial diseases, affecting the severity and frequency of clinical findings $\mathrm{s}^{23,24}$.

To ensure compliance with the above criteria and wider acceptance of the results, the WHO recommends that the assessment of AEFI causality is performed by a multidisciplinary committee comprised of experts from paediatrics, neurology, general medicine, forensic medicine, pathology, microbiology, immunology and epidemiology. In this opinion article, the problem is addressed from the standpoint of general pathology and immunopathology. In order to frame the correct perspective and scientifically founded causation assessment, it is appropriate to summarize the main mechanisms of vaccines and the possible reasons for a severe adverse reaction. This knowledge is essential in order to properly utilize the WHO algorithm, where the plausibility and temporal compatibility of an AEFI is evaluated.

\section{The complexity of reactions to vaccines}

Vaccines are mixtures of substances that cause milder forms of diseases, or mimic those of real diseases and, therefore can cause harm. The latest publication of the Italian Drug Agency (AIFA) July 30, 2019 (https://www.aifa.gov.it/), reports that serious AEFI correlated to vaccines in 2018 were 3.1 per 100,000 doses, with considerable differences between the different vaccines, for example the vaccine MPRV correlated with a rate of 12.7 reports per 100,000 doses. On the other hand, there is evidence of significant differences in rates of AEFI, according to the methods of data collection. A recent paper reported a notification rate of 3,800 correlated adverse events per 100,000 doses of measles/mumps/rubella/varicella (MMRV) vaccine (often administered together with anti-hepatitis $\mathrm{A})^{25}$. The latter publication states that the use of "active" reports data is essential for the study of adverse events defined as "rare" (those whose prevalence is less than 1/1,000 doses).

A vaccine may cause serious adverse reactions for three reasons: a) the material, that is, the content is "defective" or "contaminated", due to preparation or storage inaccuracies; b) administration errors, such as accidental intravenous injection, the injection near a nerve plexus or the delivery of aluminium in the skin instead of into muscle; c) abnormal "reaction", manifesting excessive biological stress caused by a foreign material or live attenuated virus. The most severe reactions are related to the vaccine action that involves two types, an "innate immune response", linked to the early biological defences to injected matter, and a more antigen-specific response, linked to the adaptive immune defences (Figure 1). 


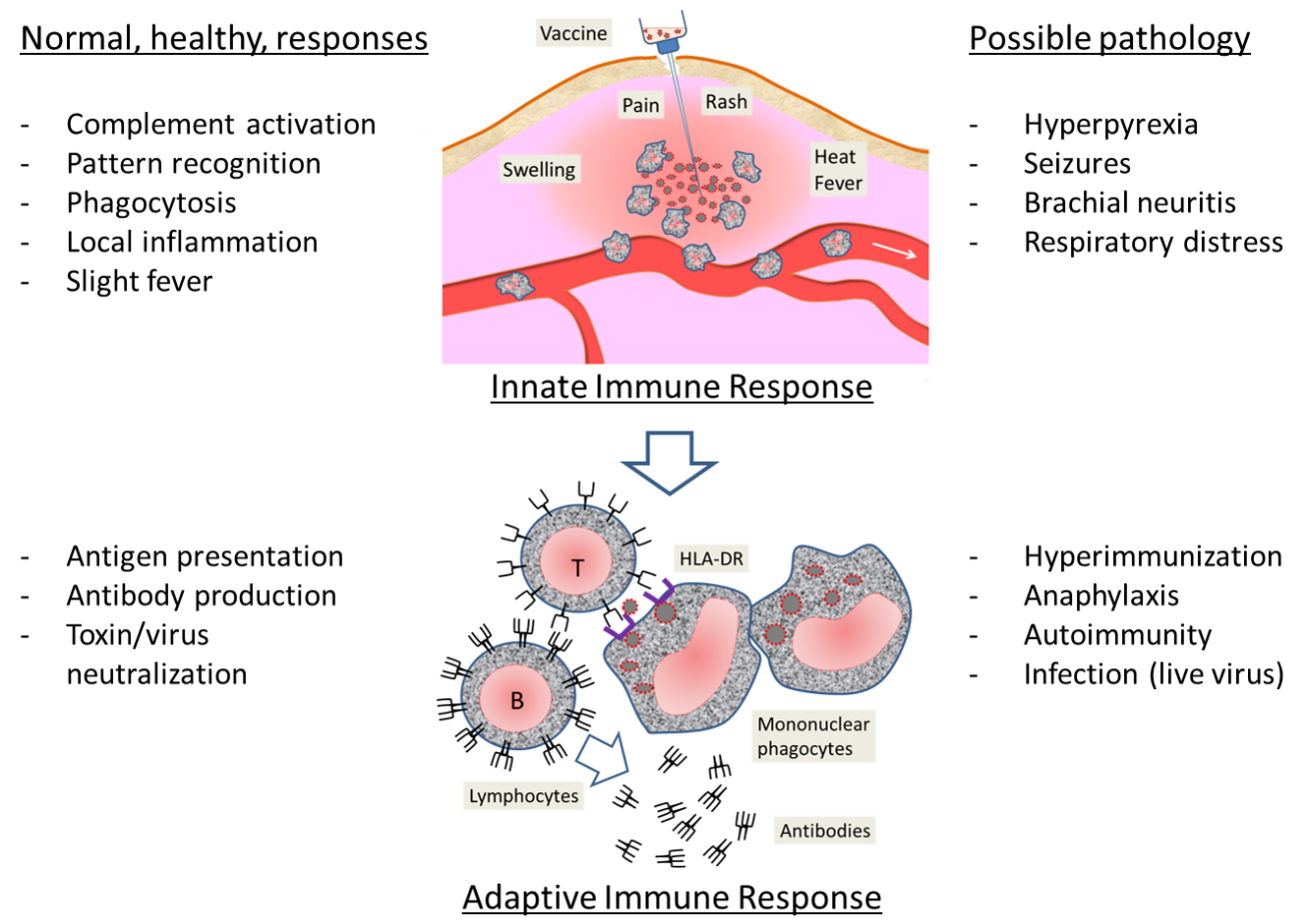

Figure 1. Innate and adaptive responses to a vaccine. Left column: normal responses; right column: possible pathology (excess/disorder of biological responses). Image is author's own, produced for this review.

\section{Innate immune responses}

The first phase immediately following the inoculation of the foreign material is the activation of a local inflammatory reaction at the point of injection, primarily involving the phagocytic cells such as monocytes and macrophages; the inflammation certainly leads to the production of cytokines by epithelial, mesenchymal and nerve cells: the release of classical inflammatory cytokines such as IL-1, IL-6, TNF-alpha, occurs a few hours after injection of aluminium-adjuvanted vaccines ${ }^{26}$. When the reaction is sufficiently strong, the local inflammatory mediators (complement, cytokines, chemotactic factors) spread and amplify the reaction at a systemic level, which explains the general and neurological symptoms in the first hours or days after the vaccine. There appears to be a strong relationship between increased concentration of cytokines and febrile reactions, lymphadenopathy and generalized rash, after yellow fever vaccination ${ }^{27-29}$.

In very general terms, the inflammatory phase becomes pathological when it is in "excess", i.e. causes negative side effects that outweigh those necessary to achieve the protective and repairing purposes. As for vaccines, fever is a useful mechanism to promote the mobilization of cellular, vascular and metabolic defences, to kill viruses and activate immunity, but it becomes "disease" beyond a certain temperature (the so-called "hyperthermia"). Conventionally, hyperthermia superior at or in excess of $39.5^{\circ} \mathrm{C}$ is considered a severe adverse reaction to the vaccine, and may cause seizures. The risk of febrile seizure increases over 5 times in children aged 12 to 35 months, within 6 to 11 days after exposure to the measles/mumps/rubella (MMR) vaccine $^{30,31}$. Compared with MMR alone, the MMRV vaccine doubles the risk of febrile seizures in children aged 10-24 months, and does not modify it in children between 4 and 6 years $^{32}$. Receipt of DTP vaccine, but not of DTaP ${ }^{33}$, was associated with a 5-times increased risk of febrile seizures on the day of vaccination ${ }^{34}$.

Febrile seizures represent a predominantly functional disorder and are generally considered relatively benign, i.e. do not leave organic brain damage. However, in the case of longer term high temperature and convulsions (complex seizures, defined as an episode $>15 \mathrm{~min}$ or recurrence within 24 hours $^{35}$ ), or in patients with cardiovascular system diseases, the brain can suffer from disturbance even on the level of cell viability, related to inflammation itself (cell damage due to excitotoxicity or to oxygen metabolites secretion by microglia), respiratory distress and anoxia. In extreme cases, prolonged hyperpyretic seizure syndrome can result in brain degeneration and/or death ${ }^{36-40}$. As for the long-term consequences, the risk of developing epilepsy after complex febrile seizures is estimated at around $10-20 \%{ }^{41}$.

A particular role may involve simultaneous injections of vaccines, because it is obvious that the type of nonspecific reactions are enhanced, if they are due to additional pathogenic factors $^{26}$. This is even more evident when you consider that vaccination is generally not recommended in children who have a febrile condition, whatever the cause.

\section{Adaptive immune responses}

The second step of the vaccine function is the activation of immune system through antigen presentation by mononuclear phagocytes to lymphocytes. At this stage, a pathologic reaction 
may consist of unwanted responses due to hyper-immunization, autoimmunity, allergy and damaging infection (the latter in case of live viruses in immunocompromised patients).

Hyper-immunization reactions for repetitions of the tetanus vaccine have been documented in the Italian population, where the prevalence of an excess of antibodies ( $>5 \mathrm{IU} / \mathrm{ml}$ ) was described in $17 \%$ of the observed subjects ${ }^{42}$. The diseases induced by hyper-immunization following the administration of vaccines are due to sensitivity to one of the components of the vaccine, and exacerbation of atopic or vasculitis symptoms $^{43,44}$. If the status of pre-existing immunity is unknown, to avoid hyper-immunization and its risks, it is recommended to carry out laboratory testing to determine antibody titre and avoid vaccination if the titre is already high enough ${ }^{45}$.

Vaccines have long been suspected of playing a negative role in inducing autoimmune diseases ${ }^{46-56}$. The most established connections between autoimmune disease and vaccinations have been reviewed ${ }^{57}$ and include: immune thrombocytopenia after MMR vaccination, Guillain-Barré syndrome after swine influenza vaccination, reactive arthritis after hepatitis $\mathrm{B}$ and rabies vaccinations, SLE and other autoimmune diseases, after hepatitis B and human papilloma virus vaccinations.

Evaluation of the association of AEFI with autoimmune diseases is challenging due the complex innate and adaptive immune responses to vaccine components (adjuvants, antigens, preservatives) that may contribute to reactogenic responses ${ }^{17}$. The specific components of the vaccines (antigens) can trigger immunity against microbial antigens, but also a self-immunity in the case of there being a molecular mimicry (similarity) between antigen protein sequences and protein sequences of components of the organism or HLA receptors ${ }^{16,52,58-60}$. The emergence of the post-vaccination autoimmune syndrome is associated with genetic predisposition, for example, HLA-DRB1 or HLA-DRB4, as a result of exposure to additional external factors or endogenous autoimmunity triggers ${ }^{61-63}$.

A typical autoimmune disease, which seems to be related to immunization in about a third of $\operatorname{cases}^{64,65}$, is SLE (Figure 2). SLE pathogenesis is very complex, subject to both environmental factors - like viruses ${ }^{66}$, bacteria $^{67}$, but also to drugs ${ }^{68}$ (and this is highly significant) - and also to genetic susceptibility (for example HLA polymorphism) ${ }^{69,70}$ as well as hormonal factors (in fact, it has a considerable prevalence in the female gender $)^{71}$. Moreover, the vaccine adjuvants can increase the immunogenicity of the injected antigens and, as a consequence, may also increase the risk of triggering autoimmune adverse events $^{56}$.

According to some authors, it may be possible to conceive the production of vaccines based solely on unique sequences of pathogens, which could then frustrate the potential risk of crossreactivity in the existing vaccine formulations ${ }^{72,73}$. Unfortunately, this approach is still utopian for vaccines currently in use.

Both local inflammatory responses and immune systemic responses are increased by aluminium adjuvants. Concerns about the safety of aluminium emerged as a result of the recognition of its biological persistence, exhibiting an unexpectedly long duration within immune and nervous system cells ${ }^{74-82}$. Aluminium adjuvant particles remain in the lymphoid organs and can even get into the brain, a phenomenon documented in animal models ${ }^{83,84}$. In particular, the long-term persistence of an aluminium granuloma, also defined as macrophagic myofasciitis, is characterized by chronic arthromyalgia, fatigue and cognitive dysfunction ${ }^{74,85}$. The problem is not just a

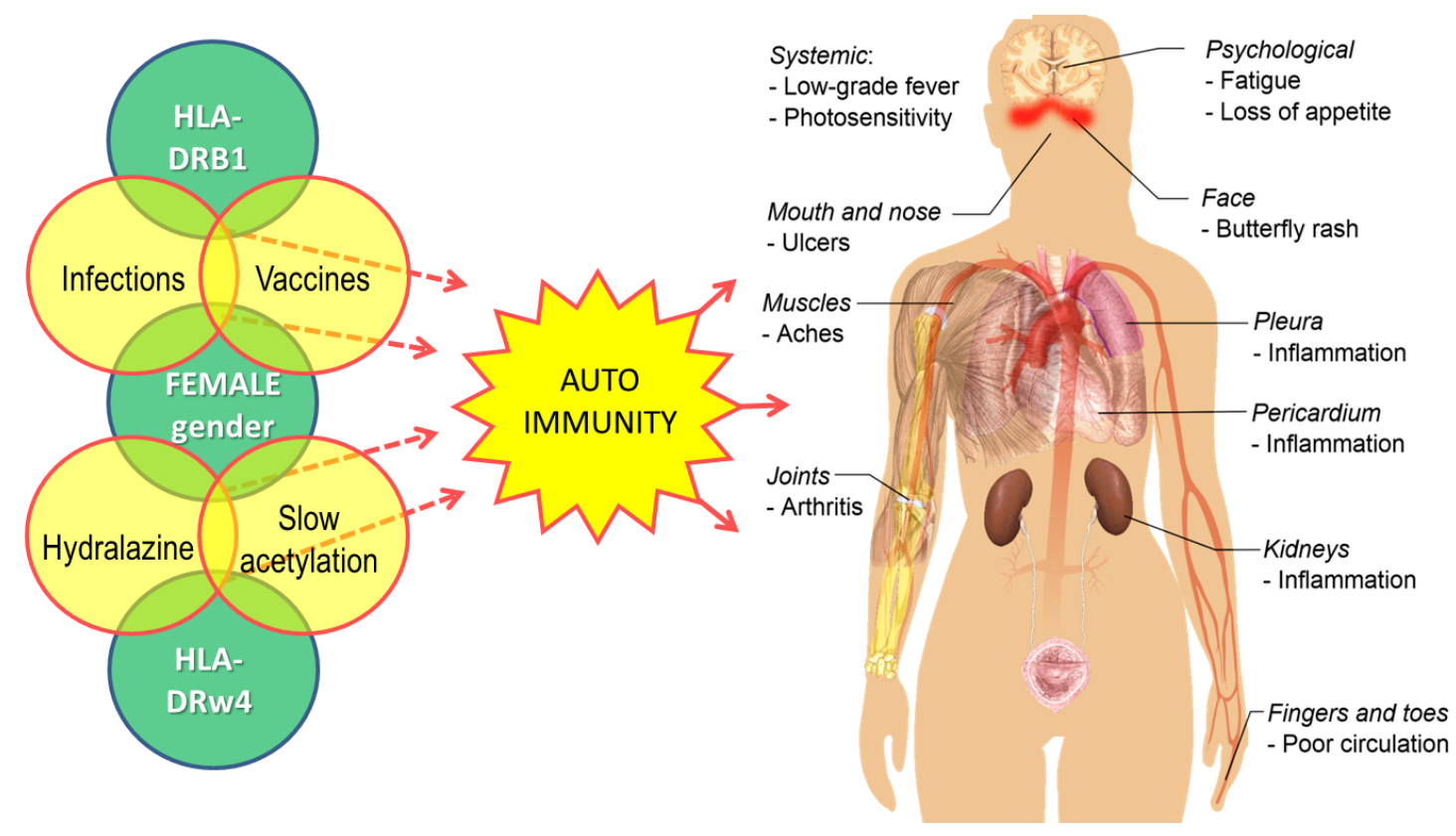

Figure 2. The multiple factors that may trigger autoimmunity in the pathogenesis of lupus erythematosus and the common signs and symptoms of the disease. The image of the body is by Mikael Häggström, used with permission (in the public domain). 
difficulty in curing local granulomatous inflammation ${ }^{86}$, but the systemic effects, such as oxidative stress on the blood ${ }^{87}$, cognitive dysfunctions ${ }^{88,89}$, chronic fatigue syndrome ${ }^{90,91}$, hypotonia ${ }^{92}$, child motor retardation ${ }^{93}$, sensory disturbances, loss of vision and cerebellar signs $^{94}$, as well as alterations of cerebral circulation ${ }^{95}$. A recent review illustrates several mechanisms by which aluminium introduced through immunizations can produce chronic neuropathology in genetically susceptible individuals ${ }^{96}$. These authors recommend that the use of aluminium salts in vaccines be discontinued in favour of adjuvants less involved in the activation of autoinflammatory and neurolesive reactions.

\section{Genetic susceptibility}

The mere fact that vaccines are followed by serious adverse effects in only a few individuals suggests that in most of these cases underlying susceptibility factors are present, which predispose or prepare the complex innate or adaptive reaction system for an excessive or biased reaction. Among these factors, it is obvious that genetically defined pre-existing conditions are at work in some groups of subjects in the population ${ }^{18}$, but research in this field is in its infancy. A genetic predisposition results from specific genetic variations that are often inherited from a parent. These genetic changes contribute to the development of a disease but do not directly cause it.

The genetic conditions that have been associated with excessive vaccine reactions can be various (Table 1), as congenital immunodeficiency, variants to the virus receptors and cytokines, epileptic tendencies, defects of detoxification inhibitors and enzymes, and so on. However, the small size of the groups,

Table 1. Genetic disorders or variants that have been associated with adverse effects following immunization.

\begin{tabular}{|c|c|c|c|}
\hline Condition & Vaccine & Possible disease & References \\
\hline Primary immunodeficiency (AGG, CID, CVID, HGG, SCID) & OPV & Vaccine-derived polio & 97 \\
\hline Primary immunodeficiency (SCID) & Rotavirus & $\begin{array}{l}\text { Severe persistent diarrhoea, } \\
\text { vomiting, failure to thrive }\end{array}$ & $98-100$ \\
\hline Primary immunodeficiency (SCID) & $B C G$ & Severe tuberculosis, death & 101,102 \\
\hline $\begin{array}{l}\text { Primary immunodeficiency (CD8 deficit, } \\
\text { dysgammaglobulinaemia) }\end{array}$ & MMR & Encephalitis & 103 \\
\hline Polymorphisms of MBL and TLR receptors of innate immunity & BCG & Osteitis & 104,105 \\
\hline Polymorphism of purine receptor $\mathrm{P} 2 \mathrm{X} 7$. & $B C G$ & BCG lymphadenitis & 106 \\
\hline Polymorphism of IL17A & BCG & Osteitis & 107 \\
\hline Specific haplotypes in the MTHFR and IFR1 & Smallpox & Generalized skin eruptions & 108 \\
\hline Specific haplotypes in the IL 1 and IL18 genes & Smallpox & Systemic symptoms, fever & 109,110 \\
\hline Polymorphism of IL-4 & Smallpox & $\begin{array}{l}\text { Decreases susceptibility to } \\
\text { systemic adverse events }\end{array}$ & 109,111 \\
\hline SCN1A mutations & DTP & Epileptic encephalopathy & $112-114$ \\
\hline SCN1A, SCN1B or PCDH19 mutations (Dravet syndrome) & DTP, DtaP, and MMR & $\begin{array}{l}\text { Epileptic seizures, autism-like } \\
\text { symptoms }\end{array}$ & $115-117$ \\
\hline $\begin{array}{l}\text { Polymorphisms of interferon-stimulated gene IFI44L and } \\
\text { CD46 (receptor for measles virus) }\end{array}$ & MMR & Febrile seizures & 118 \\
\hline SCN2A mutations & MMRV & $\begin{array}{l}\text { Episodic ataxia, impaired } \\
\text { speech development }\end{array}$ & 119 \\
\hline Mutations in the catalytic subunit of PI3K & Varicella & Disseminated varicella & 120 \\
\hline Mutation in IL17R & Varicella & Disseminated varicella & 121 \\
\hline $\begin{array}{l}\text { Polymorphisms in chemokine receptor CCR5 and its ligand } \\
\text { RANTES genes }\end{array}$ & Yellow fever & $\begin{array}{l}\text { Viscerotropic disease, multiple- } \\
\text { organ system failure }\end{array}$ & 122 \\
\hline HLA-DQB1*06:02 and polymorphism of T-cell receptor-alpha & $\begin{array}{l}\text { AS03 adjuvanted } \\
\text { A/H1N1 }\end{array}$ & Narcolepsy & 123,124 \\
\hline Polymorphism of GDNF-AS1 & $\begin{array}{l}\text { AS03 adjuvanted } \\
\text { A/H1N1 }\end{array}$ & Narcolepsy & 124 \\
\hline HLA-DRB $1 * 01$ & $\begin{array}{l}\text { Aluminium-hydroxide } \\
\text { adjuvanted vaccines }\end{array}$ & Macrophagic myofasciitis & 125 \\
\hline HLA-DRB1 ( $\left.{ }^{*} 01: 01,{ }^{*} 03: 01,{ }^{*} 04: 01,{ }^{*} 13: 01,{ }^{*} 15: 01\right)$ & Hepatitis B & Autoimmunity & $62,126,127$ \\
\hline $\begin{array}{l}\text { HLA-DRB1*1102/1132, DRB3*0202/0202, DQA } 1^{*} 0505 / 0505 \text {, } \\
\text { DQB1*0301/0301 }\end{array}$ & Hepatitis B & Systemic Lupus Erythematosus & 70 \\
\hline Type 1 GSD & Any & Hypoglycaemia & 128 \\
\hline
\end{tabular}

AGG: agammaglobulinaemia; CID: combined immunodeficiency; CVID: common variable immunodeficiency; HGG: hypogammaglobulinaemia; SCID: severe combined immunodeficiency; MBL: mannose-binding lectin; TLR: toll-like receptor; MTHFR: 5,10-methylenetetrahydrofolate reductase; IRF1: interferon regulatory factor-1; SCN1A: sodium channel, voltage-gated, type I, alpha subunit; PCDH19: protocadherin 19; P2X7 is a purine (ATP) receptor; IL17R: interleukin-17 receptor; PI3K: phosphatidylinositol-3-kinase; AS03: adjuvant systems 03 (oil-in-water emulsion); GDNF-AS1: glial-derived neurotrophic factor antisense RNA-1; GSD: glycogen-storage disease. 
the often anecdotal type of the reports, and the multifactorial nature of diseases, do not allow us to draw definitive conclusions on causality regarding the observed associations between genetic types, vaccine and reported outcomes.

Febrile seizures are genetically complex disorders, believed to be influenced by variations in several susceptibility genes ${ }^{129}$ and, among the susceptibility genes, by those encoding cytokines of the acute phase ${ }^{130}$. The risk of post-vaccination febrile seizures increased in subjects with previous and family history of febrile convulsions, showing that in some subjects there is a predisposition, which is obviously a co-factor in determining the risk of the vaccine ${ }^{131,132}$. The latter authors suggested that in order to reduce the risk of adverse reactions to MMRV, children with a family history of febrile seizures should not be vaccinated. Two loci were clearly associated with febrile seizures MMR-related, but not with those from other causes ${ }^{118}$ : the IFI44L interferon-stimulated gene and the CD46 receptor for measles virus. It is interesting that the same IFI44L and CD46 genes are among those that affect the magnitude of the antibody response to measles ${ }^{133}$.

Among the genetic factors and in particular polymorphisms, the role of SCN1A gene mutations is demonstrated by the fact that the risk of post-vaccine seizures increased in patients with Dravet syndrome, a severe epileptic encephalopathy ${ }^{114,116,134}$. Vaccination is the trigger of the first seizure in about $50 \%$ of cases $^{135}$, while the vaccination program does not seem to increase long-term consequences of the disease on cognitive function. In children, genetic or structural defects are an underlying cause of epileptic seizures onset, after routine immunization, that may act as a triggering factor ${ }^{136}$ and these authors suggested that early genetic testing should be considered in all children with vaccination-related onset of epilepsy. In this context, it is important to point out that live vaccine may be safely administered to children with Di George syndrome, a congenital T-cell defect associated with a deletion in chromosome 22 (22q11. 2 deletion) $)^{137}$.

As a first step towards a systematic collection of genetic susceptibility factors, Lin, $\mathrm{He}$ and Xie have created an ontological framework (Ontology of Genetic Susceptibility Factors, OGSF), which may provide guidance for representing diverse types of genetic susceptibility factors for vaccine adverse events, such as HLA alleles, SNPs, genes, and gene haplotypes ${ }^{138-140}$.

\section{The microbiome}

In the complex mechanisms regulating the innate and adaptive responses to immunization, the role of the microbiome and of the intestinal barrier should be noted as important factors that may contribute to systemic inflammatory reactions ${ }^{141-143}$. Bacterial endotoxins that may be released from the intestine, in the case of increased intestinal permeability (also possibly caused by medication or dysmicrobism), should not be neglected. The interactions between products of the bacterial microbiome with immune cells trigger self-reactivity, chronic inflammation and tissue damage in genetically sensitive subjects ${ }^{144,145}$. The synergy between LPS and inflammatory cytokines is one of the simplest and most ubiquitous mechanisms of neuroinflammation and neurodegeneration ${ }^{143,146-148}$. This can happen through the modification of substances by the intestinal bacterial flora, which can therefore become autoantigens and mistakenly trigger immune responses of the wall itself. In addition, recent studies have shown that a breakdown or increase in permeability of the intestinal barrier and the translocation of commensal bacteria or endotoxins into non-intestinal organs can trigger several autoimmune pathways $^{141-143,149}$. For example, many people with multiple sclerosis have been shown to have an altered microbiome, increased intestinal permeability and changes in bile acid metabolism ${ }^{150}$. Allergic diseases and autoimmune encephalitis have also been correlated with changes in intestinal microbiota $^{151}$. For these reasons and as a precautionary measure, the healthy state of the gut should always be considered, before a vaccination procedure.

\section{WHO guidelines}

WHO guidelines for causality assessment were published in $2013^{152}$ and updated in $2018^{1}$ (https://www.who.int/vaccine safety/publications/gvs_aefi/en/). The first step is to determine if the AEFI is "eligible", meeting the minimum criteria for the assessment of causality, such as the presence of a clear diagnosis. The second phase ("checklist") encompasses a systematic review of relevant and available information to deal with possible causal aspects of the AEFI. Then, an "algorithm" synthesizes the entire conceptual and methodological process in four steps (Figure 3). Given the central importance of the WHO algorithm, for brevity and clarity of need, this article will focus on these steps, with four notes highlighting the main problems that emerge in the light of the previous discussion on the possible mechanisms of vaccination adverse reactions.

\section{Note 1. The "other causes"}

The WHO algorithm of step 1 rules out the association of an AEFI with vaccination if there is another cause. This is the first and decisive criterion for exclusion and is stated on the "checklist", alongside the question "Is there strong evidence for other causes?" The text then further explains that a detailed medical history, clinical examinations and investigations, including laboratory tests on the patient, can help identify other conditions such as other diseases and congenital anomalies that may have caused the event. Provided is the example of the death of a girl, following vaccination against human papilloma virus (HPV), where a post-mortem examination accredited the cause to a malignant mediastinal tumour.

It should be noted that, in this first phase, the process systematically seeks another "strong" cause which, if found, would exclude the causal link. This concept of "strength" is not defined and can be misunderstood. According to medical historian Cosmacini ${ }^{153}$, causality criteria are changing due to epidemiology of modern diseases: a strong causality criterion arises when the pathogenic cause, for example, the infectious agent, is "forcibly" followed by pathological effect, i.e. the disease or event; while a weak causality is when the cause has "less strength" or "relative weakness". In these second possibilities, the relative weakness lies in the fact that the pathogenic 


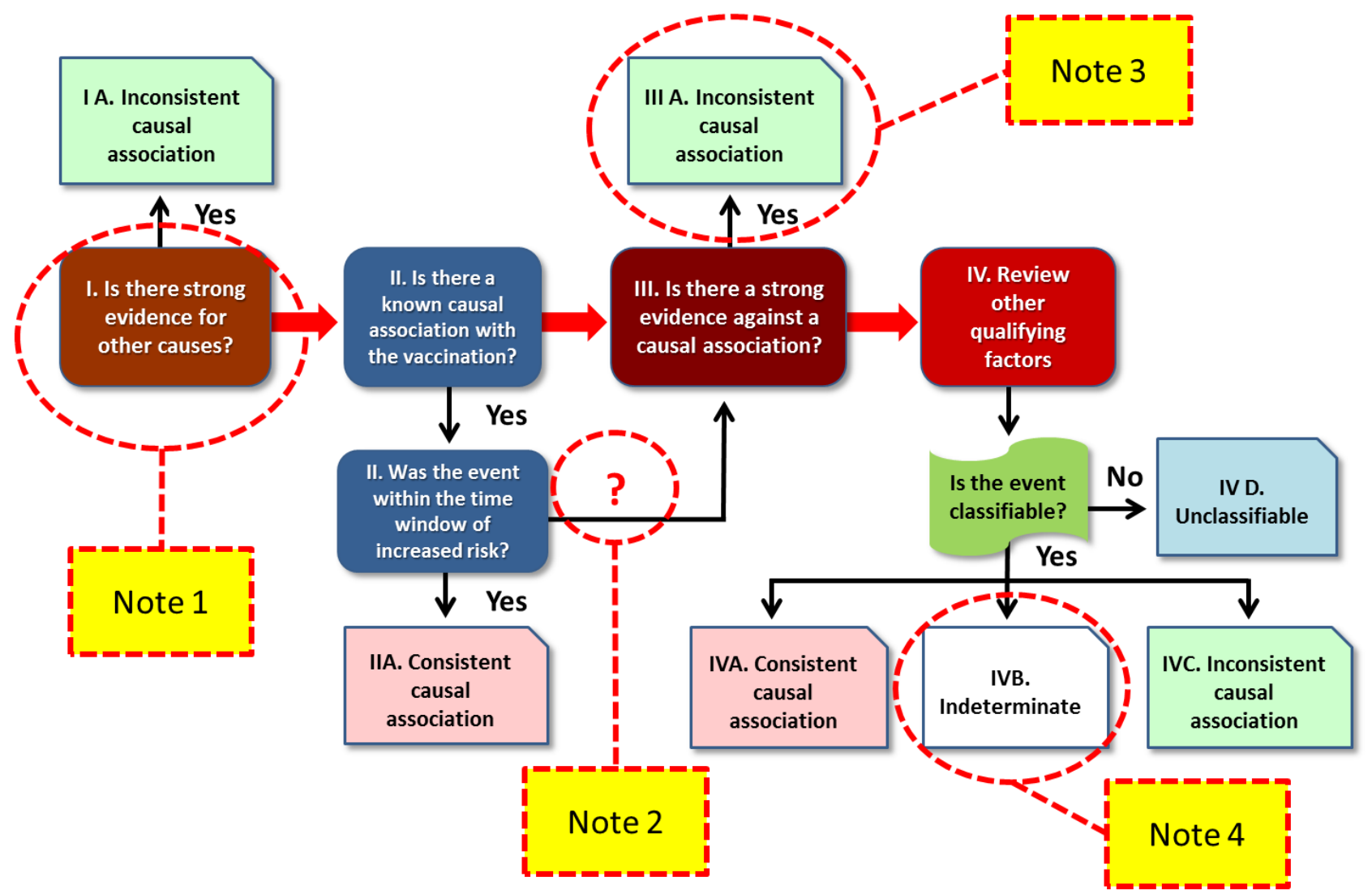

Figure 3. The WHO algorithm for causality assessment of AEFI, with the indicated notes discussed in this opinion article (yellow boxes).

cause or causes are probabilistically followed by the morbid effects. As explained above, in the presence of many possible causes, none of which is necessary or sufficient to determine that disease, the traditional concept of cause is transformed into the new concept of "risk factor." The multifactorial perspective, deriving from the observation of adverse reactions from the vaccine and from the recent knowledge of pathology and immunopathology (see above sections), means that the concept of "strength" of causal association takes on a probabilistic meaning.

This is a very important aspect and should not be overlooked. If a disease is multifactorial in its nature, to be considered strong enough to exclude the contribution of a vaccine, the "other cause" must be independent of a possible synergistic interaction with the effects of the vaccine itself on the immune responses. For example, a complication of an advanced tumour, after pneumococcal vaccination can be considered "the" cause of death (as in the example provided by WHO guidelines), but a HLA haplotype that predisposes to autoimmunity cannot be considered "the" cause of an autoimmune disease that arose after the hepatitis vaccination.

Note 2. Biological plausibility and the time window

The second step of the algorithm (Figure 3) includes the evaluation of the "positive" elements that could be in favour of a consistent causal relationship, considering the biological plausibility and whether the event occurred inside a time window compatible with the risk after vaccination. If all these aspects are in favour of a role of the vaccine in the AEFI, without negative evidence, the causal association is classified as "consistent". The biological plausibility of damage from the vaccine can be inferred by its known action: in some rare and susceptible individuals, an abnormal response to the stimulus, provided by antigens and adjuvants, unfortunately occurs. The person who has suffered damage from the vaccine usually was predisposed via some "risk" factor - genetic or acquired - which was not sufficiently "strong" to cause illness or injury. With vaccination moreover, the organism is destabilized leading to a pathological reaction. From this point of view, a steadier plausibility of a consistent association between disease and vaccine is generated, if two conditions occur: a) the same pathology (or a biologically similar one) has already been described in other cases after vaccination and b) the subject is a carrier of an increased proneness to that particular pathology.

Concerning the "time window" in which an AEFI can be considered as putatively associated with vaccination (box II in Figure 3), the questions are usually clear enough and should not pose significant issues, at least when previously described cases exist and for the "acute" cases (hours or days after 
vaccination). However, problems can be substantial when considering chronic illness and autoimmune disease, which can develop quite some time after vaccination. For autoimmune diseases, the difficulty is even greater because, as we have seen, they are "weakly" associated with vaccination. For example, a systematic review and meta-analysis suggests that vaccinations significantly increase the risk of $\operatorname{SLE}(\mathrm{RR}=1.50$; 95\% CI 1. 05-2. 12, $\mathrm{P}=0.02)$ and rheumatoid arthritis $(\mathrm{RR}=1$. 32; 95\%CI 1. 09-1. 60, $\mathrm{P}=0$. 004) ${ }^{65}$. This means, from a theoretical point of view, that about one in three SLE cases may also occur via the vaccine. However, among all people with SLE, we cannot say for whom the vaccine has had a causal role; we can only say, for a person who has had the appearance of SLE after vaccination, that there is about a 3 in 10 chance that vaccination has contributed negatively to the development of the disease.

It should be noted that eight patients with disseminated acute encephalomyelitis occurred less than 10 weeks after vaccination against hepatitis $\mathrm{B}(\mathrm{HBV})$ have been reported ${ }^{154}$. Another case, which occurred 3 weeks after $\mathrm{HBV}$ vaccination, has been described more recently ${ }^{155}$ and 93 patients with autoimmune disease after HBV vaccination have been reported ${ }^{47}$. The mean latency period since the last dose of vaccine and the onset of symptoms was 43 days. However, studies of cohorts of children with neurological and behavioural syndromes (e.g. anorexia nervosa, attention deficit hyperactivity disorder, obsessive-compulsive disorder) have observed an increased risk of up to 12 months after vaccination ${ }^{156}$. On the other hand, given the multifactorial nature of most chronic diseases, it cannot be excluded that, over a longer period, other causes determining the chronic pathology, unrelated to the vaccine, may well have occurred. Consequently, in the perspective of a single case, it is very probable that the undesired reactions which arose at a considerable distance from the vaccination escape the possibility of proving a causal association.

Incidentally, it should be noted that the WHO algorithm published in 2018 (Figure 3) lacks the indication "No" over the arrow connecting phase II box "Was the event within the time window of the risk?" with the phase III box "Is there a strong evidence against a causal association?". As a matter of fact, in the algorithm of causation assessment published in 2013 there did appear the inscription "No" on the connection arrow ${ }^{157,158}$. This omission in the recent algorithmic form can create misunderstandings, because those who follow the algorithm literally would be prevented from concluding with IIA ("Consistent causal association") and would necessarily proceed to phase III, a passage where again an exclusion criterion is offered, mostly linked to literature (see below). Thus the path proposed by the arrow would defeat any chance of reaching the IIA conclusion, although other evidence is favourable to a positive causation. To avoid any such misunderstanding, it would be more correct and reasonable to restore the previous descriptor "No" to the aforementioned connection.

\section{Note 3. The literature}

In phase III of the algorithm, users must answer these key-questions "Is there strong evidence against a causal association?" and "Is there a body of published evidence (systematic reviews, GACVS reviews, Cochrane reviews, etc.) against a causal association between the vaccine and the event?" This is a criterion used in a very "strong" way, even to the point of excluding a case for lack of evidence of literature, leading to conclusion IIIA ("Inconsistent causal association"), even if there is plausibility for a consistent association and a compatible time. The topics reported as emblematic are autism and sudden infant death syndrome (SIDS), as it is argued that according to the literature they cannot be caused by the vaccine. Specifically, the guidelines ${ }^{1}$ write that "no evidence exists of a causal association between MMR vaccine and autism or autistic disorders" and that "the committee concluded that vaccines did not cause SIDS." Here we must pay attention to language and related concepts, because the "lack of evidence of association" may become easily, but mistakenly, "evidence of the lack of association". It would not be correct to use this lack of knowledge as a "guillotine" criterion to exclude causation in individual patients. In fact, epidemiological studies cited in the document may exclude an association at the population level but do not have the power to exclude rare cases, especially if the surveillance is not $100 \%$ efficient.

In a Cochrane review of $2012^{30}$ the design and reporting of safety outcomes in MMR vaccine studies, both pre- and postmarketing, are defined as "largely inadequate". The question is how one can exclude any liability of the vaccine in contributing to the development of serious neurologic adverse effects, at least in sporadic cases of children predisposed via other genetic factors. The genetic background of autism is known (about a quarter of cases of autism have a genetic basis although only in rare cases is the disease totally genetic) but encephalopathy may also be determined by autoimmunity ${ }^{159-163}$, which, in turn, depends on some factor of an antigenic nature. It should also be noted that "autism" is not a disease with specific symptoms and reproducible in all subjects with personality disorders, so that we speak of "autism spectrum disorders". The most obvious case of a possible overlap between autism spectrum symptoms and another disease, surely caused by vaccine adjuvants, is the macrophagic myofasciitis ${ }^{164-167}$.

Regarding SIDS (otherwise known as SUDC, sudden unexplained death in childhood), the considerations are partly different. SIDS (or SUDC) is strictly defined as "unexplained crib death from known causes upon autopsy" ${ }^{38}$. The prevailing literature, as rightly reported by WHO, states there is no association between SIDS, SUDC and vaccination. This is completely obvious, because if in a case of "death in a cradle" there is no symptom of particular diseases, nor any autopsy findings that can highlight the cause, this means that the role of the vaccine cannot be proved either. On the other hand, what the WHO algorithm can't exclude is a violent adverse reaction to the vaccine components that can result in death in particularly fragile subjects. This type of reaction would not correspond to the definition of "SIDS" or "SUDC". For this reason, in the case of a sudden death of a child after vaccination, before adopting the exclusion criteria of Phase III, the analysis of the case should exclude any clinical evidence (e.g. high fever, convulsions, respiratory distress, syncope) 
and autopsy finding (e.g. cerebral congestion, pneumonia, isolation of vaccine virus strain, significant increase of some cytokines in the blood) of strong inflammatory reactions. It was reported that in six cases of children who died in the crib after hexavalent vaccine and were previously diagnosed as "SIDS", the autopsy revealed severe signs of encephalitis and other laboratory data indicating systemic inflammation ${ }^{168}$. The literature does not exclude the fact that pneumonia is rarely as a result of vaccination, since cases of the syndrome have been reported in deceased patients after DPT vaccination ${ }^{169}$, influenza ${ }^{170}$, and anti-haemophilus influenzae type $b^{171}$. In summary, the benchmark linked to the scientific literature is important for the final categorisation (step IV), but should not be considered as a decisive criterion leading to conclusion IIIa, i.e. to exclude causal association in individual cases.

\section{Note 4. The final categorisation}

Eventually, the evaluation process ends with a global assessment, according to four categories: "consistent" when the causal association between the event and the vaccine is considered plausible, "inconsistent" in the presence of other causes which can justify the event, "indeterminate" when the evidence is insufficient to support a causal relationship in the presence of confounding factors, and "unclassifiable" when the information necessary to carry out the assessment is inadequate.

Apart for the "unclassifiable" cases, for which there is no possible classification, the other categories must be discussed and weighed carefully. The distinction between "consistent" and "inconsistent" could possibly apply to some clear-cut cases, but it becomes forced when you see the adverse reaction to the vaccine manifesting itself as a complex and multifactorial process, wherein the predisposing conditions and the trigger are contributory causes, with different pathogenic mechanisms. The perspective adopted in this report implies that although different causes contribute to an adverse event following immunization, they cannot be considered necessary and sufficient "causes" of the event per se except in very special cases. This problem is not just a difficulty of language and definition, but reveals the conceptual approach adopted by WHO in the preparation of the guidelines in question, under which one proceeds "by exclusion", in search of an "other cause ". But if the abnormal reaction to the vaccine (which has already been made in the diagnosis) has a multifactorial origin, proceeding by elimination of one or more con-causes is incorrect from a scientific perspective. For example, if a child affected by a serious heart condition, dies the day after vaccination, which led to strong fever and/or difficulty breathing, the most plausible hypothesis is that the effect was determined by the "cooperation" of two factors, both important and interacting, but none of which alone could explain the event, without the other. This point was already raised by Puliyel, Naik and Phadke who noted that, according to the WHO algorithm, a cardiac decompensation in children with an underlying heart disease "would not be considered causally related to the vaccine, although vaccination contributed to cardiac failure" ${ } 158,172$.
A problematic approach to the causal assessment appears where the guidelines ${ }^{1}$ state that "In doing causality assessment on an individual case report, it must be remembered that in essence one is conducting a differential diagnosis" (page 7) and that "it is important to recognize that causality assessment of an AEFI in an individual patient is an exercise in medical differential diagnosis. A good clinician does not diagnose diabetes or coronary artery disease on the basis of conflicting or vague information. In the same way, an AEFI should not be causally linked to a vaccine without adequate information" (page 34). Giving examples of such "differential diagnosis" can be misleading, because normal clinical activity is very different from causality assessment. In fact, the "differential diagnosis" of a multifactorial disease normally is not based on the cause but on its clinical manifestation, that is, the signs and symptoms, the pathological findings, and laboratory results. On the other hand, in the case of an AEFI one is not conducting a "diagnosis" of the disease (also here the WHO procedure provides for a diagnosis be made from the beginning, otherwise the case is not even "eligible"), but is trying to determine what was the sole cause or were the plural causes of the reported adverse event.

To illustrate how the application of the WHO algorithm is difficult and potentially error-prone, three case studies are presented (Box 1) in which the death of children occurred within a short period of time after vaccination. These cases are described in the AIFA reports of vaccine surveillance of AEFI relating to 2016, 2017 and 2018 years (https://www.aifa.gov.it/rapporto-vaccini). In all reported cases the causality link with the vaccine was excluded because of the presence of "other causes". These examples raise some questions and deserve clarification, without which a high risk of misinterpretation exists. The notes of the author concern a) whether the alternative "other cause" was sufficiently clear and "strong" as a diagnosis and as a possible cause of death and b) whether or not there could be a plausible interaction between the pre-existing clinical conditions and the biological action of the vaccine.

\section{Concluding remarks}

Although all licensed vaccines are generally safe for the majority of people, the vaccinated may still suffer adverse events in reaction to various vaccines, a few of which can be serious or even fatal ${ }^{140,173}$. Regarding public health, the proper identification and classification of AEFIs allows for the most accurate information possible about the true frequency of certain ailments in combination with vaccines, thereby minimizing vaccine risks, reassuring the population and informing national or global public health strategies. Regarding the damaged individual, a sound causality assessment supports the affected individual (or family) pursuing any compensation scheme(s), if a consistent association of his/her illness with vaccination is demonstrated. Italian law, n. 210/1992, provides for such compensation in the form of a monthly allowance from the State to any person who has been, due to mandatory (or recommended) vaccination, the subject of injury or illness from which is derived a permanent impairment of physical 


\section{Box 1. Childhood mortality cases reported by AIFA*.}

\section{Case 1:}

Case cited in AIFA 2017 Report for 2016: "Preterm baby girl (born after 34 weeks growth in utero), vaccinated at 11 weeks with Infanrix xexa, Prevenar 13 and Rotarix. (. . .). The death occurred about 20 hours after vaccination, due to sudden death classified by the whistle-blower as "death in a cradle". The autopsy study revealed signs of pulmonary and meningeal congestion and a finding of liver vacuolization compatible with lipid metabolism disease. The causal link was not correlated with vaccination, due to the detection of another possible known cause of death (congenital defect of lipid metabolism) [references 1-3]."

In this case, the role of another possible known cause of death seems to be clearly described: the autopsy finding of "liver vacuolization" as "compatible" with the lipid metabolism disorder, but it is certainly not an accurate diagnosis. Given that the autopsy showed "lung congestion and meningitis," how does this finding connect with an inborn error of lipid metabolism, which until then had presented no clear symptoms and was never diagnosed? To justify the possible "death in crib", the genetic variant apoEe4 $4^{174}$, is then cited in bibliography no. 3 leaving it to be understood that this defect could be the cause of death in the cradle. However, given a careful reading of the work, apoEe4 has equal prevalence in children with SIDS and healthy children. Furthermore, apoEe4 does not appear to cause liver vacuolization. Finally, in the hypothesis that the girl had a disease of lipid metabolism, how is it excluded that 3 different vaccines injected simultaneously may have been the trigger, since signs of lung and meningeal congestion were detected (more compatible with systemic inflammation than with lipid metabolism disease)? It is known that respiratory distress is described as an adverse reaction to hexavalent and encephalitis (remember meningeal congestion) and in rare cases has been associated with vaccination ${ }^{113,175}$. It should be remembered, moreover, the vaccine data sheet hexavalent provides that "when Infanrix hexa is co-administered with a pneumococcal conjugate vaccine or with the vaccine MPRV, the rate of febrile reactions is higher in comparison to what occurs as a result the administration of Infanrix hexa alone " and that on the data sheet of the vaccine Rotarix, it is indicated that vaccination "should be postponed in babies, who have a sudden high fever, diarrhoea or vomiting. "In brief, the question is whether or not, in a case like this, the "other cause" is "strong" enough to exclude the possible pathogenic effects of the vaccine, when the autopsy and the time window are compatible.

\section{Case 2:}

Case cited in AIFA Reports for 2016 and 2017: "20-month-old infant vaccinated with Neisvac-C. Two days after the administration of Neisvac $C$, reported feverish rise followed by death after a few hours. The whistle-blower reports that, at the time of the sanitary intervention, it was only possible to ascertain death. The death was diagnosed as "Sudden Unexplained Death in Childhood, SUDC" as a result of "hyperpyretic hyporeactivity" in the course of respiratory infection with viral aetiology and body temperature at the time of death at $41^{\circ} \mathrm{C}$, arisen 52/53 hours after vaccination. Considering this evaluation, the causal link is "not related" to vaccination due to the simultaneous presence of another cause."

The SUDC is by definition "the sudden and unexpected death of more than one year old postnatal child that remains unexplained after a review of the medical history, the circumstances of the death and a complete autopsy" 38 . So, how this "diagnosis" of SUDC is to be reconciled with "respiratory infection with viral aetiology," remains to be clarified. Either it is respiratory infection, or a SUDC. Moreover, the attribution of the pathology to a viral aetiology remains unexplained, given that no virus was isolated and that "at the time of the intervention of the health workers, it was only possible to ascertain death". Finally, the "hyperpyretic hyporeactivity" as a possible cause of SUDC is totally speculative, given that this condition/diagnosis/symptom is not described in any scientific literature. In this case, there is biological plausibility and a time window compatible with a pathogenic role of the vaccine in the triggering of an extremely strong inflammatory systemic reaction: a strong fever is a very common consequence (1-7\% of cases) of vaccination with Neisvac-C and which can occur in the first 6 days ${ }^{176}$. Why was the causal link excluded a priori without considering the vaccine at least as a "contributory" cause?

\section{Case 3:}

Case reported succinctly in the report AIFA 2018: Serious adverse reaction to hexavalent plus pneumococcal vaccines, where death was found "not related on the basis of available information": 6-month-old male patient with Down syndrome and congenital heart disease diagnosed as Fallot tetralogy associated with a complete atrioventricular septal defect-Rastelli type A, already subject to hypoxic crises in relation to paraphysiological stimuli".

Down syndrome itself does not cause death; heart disease is certainly a potentially fatal condition but often has a chronic course so that it has also been treated surgically, even in a patient with Down syndrome ${ }^{177}$. However, in this case there is no certainty about the cause of death, i.e. evidence that the congenital malformation resulted in death on that occasion, independently of the vaccine delivered right before. No autopsy evidence is reported from which it can be understood if it was a hypoxic crisis, or signs of systemic, pulmonary or if cerebral inflammation had been detected. To rule out the role of the vaccine, in a case like this it would be important to know if the child had developed a fever, also in light of the fact that two vaccines were administered simultaneously (see note on Case 1). The problem is significant because if there had been systemic inflammation (reported by fever or other serum laboratory findings), the biological plausibility of the interaction with the vaccine would exist. In a child who certainly has a strong underlying pathophysiological fragility ("hypoxic crises in relation to paraphysiological stimuli"), how can it be excluded that simultaneous injection of hexavalent and pneumococcal vaccines (both of which are known to cause adverse reactions with respiratory diseases and therefore hypoxic crisis) may have contributed to the cardiovascular arrest? In a case like this, the "other cause" of death seems "strong", but it is not "independent" of a possible triggering effect of the double vaccine.

*https://www.aifa.gov.it/rapporto-vaccini. The translation from the original Italian text is by the Author. 
and psychological integrity. In Italy, 691 people have been recognized as permanently damaged by vaccinations, including 27 deaths (http://www. condav.it/).

This article has described the complexity and variety of adverse reactions to vaccines, from the perspective of general pathology and immunopathology. The consideration of the action mechanisms of vaccines, which is connected to the plausibility that a response to stress can be excessive or distorted in some cases, suggests that some aspects of the WHO procedure of causality assessment are inadequate to deal with this complexity. The rigid exclusion criteria which occurs in some steps of the algorithm (such as the "another cause" of AEFI in step I and the negative evidence in literature) can be a source of errors, or at least questionable interpretations, especially when the clinical situation or the autopsy are not clear and decisive. Error of evaluation would be to consider as "the cause" of AEFI any pathology that may be present at the time of vaccination, without considering the possible interaction between this pathology and the effect of the vaccine as a possible contributing cause.

Three case studies of causality assessment have been reported here (Box 1), which led to an exclusion of the causal link. The few data that were officially communicated by the regulatory authorities (AIFA) in their reports do not allow direct criticism of the conclusions reached, but are sufficient to illustrate the difficulties that may arise, in practical terms, in applying the algorithm in cases of complex clinical situations. Especially if the clinic or laboratory indicates that the AEFI derives from a multifactorial pathogenesis, it would not be correct to discard in this way a possible role of the vaccine in determining a serious adverse reaction, which obviously involves a series of conditions predisposing a body to damage. In fact, in the case of pre-existing or concomitant pathology, which can be considered a susceptibility factor, the vaccine could represent a contributory, triggering, or worsening condition.

From these considerations, a first operative suggestion emerges. To avoid potential errors of interpretation, it would be appropriate that in the WHO guidelines of the causality assessment be explicitly specified that the "other causes" mentioned in step 1 , should only be considered a reason for excluding the causal link, when they are "independent" of the possible vaccine biological action. In other words, to declare "inconsistent" the association with the vaccination, it should be excluded that the condition existing in the subject at the time of the damage may have interacted with the vaccine, enhancing its pathogenic potential (or vice versa the vaccine had worsened the pre-existing situation). Only in this situation, would it be correct to exclude the association between AEFI and vaccine action in phase I. In order for this prospect to materialize, the risk factors of vaccine reactions need to be better identified including additive (non-synergistic) and multiplicative (synergistic) forms, similarly to what has been done in other fields. Improved understanding of risk factors would contribute to reducing the uncertainties of vaccination choices, which are often perceived by the population as "leaps in the dark".

A second topic of discussion concerns the claims for compensation for vaccination damage. Due to the inherent complexity of the pathogenesis of vaccination reactions, an absolute certainty of the causal role of the vaccine is always difficult, but often it is also difficult to exclude it. Using the WHO algorithm slavishly, it is likely that many adverse events, due to various concomitant factors, will end up as "indeterminate". This conclusion could gather many cases in which plausibly the vaccine damage may have occurred, but there is neither absolute certainty, nor adequate representation in the literature. For claimants, an "indeterminate" causal link is equivalent in practice to the conclusion of "unrelated" and is therefore potentially a reason for discrimination. The latter problem, with human and economic sides, could be addressed, for example, by considering the possibility of assigning compensation perhaps in part - even if the hypothesis of vaccine damage is only "probable" and in any case its contributory role cannot be excluded.

The difficulties that courts encounter when deciding on compensation claims in which scientific uncertainty is present are noteworthy, also because the case law of different countries like Germany and France diverge with regard to their relationship to scientific criteria of causality ${ }^{4}$. In the Italian system, in the matter of civil liability, it is sufficient that the causal link between fact and harmful event occurred with a probability of $50 \%+1$ so that Civil Liability can be affirmed (See ex multis. Cass. Civ. Sent. N. 21619/2007). The aforementioned criteria have also applied to damages, deriving from compulsory (or strongly recommended) vaccinations. Indeed, the jurisprudence of the Supreme Court of Cassation has ratified the principle with multiple judgments (see Ex multis Cass. Civ. Sec. VI Judgment no. 25119/2017; Cass. Civ. Sez. Lavoro, Judgment no. 22078/2018) according to which the existence of the causal link between the vaccination administration and the occurrence of the damage to health must be evaluated according to a criterion of reasonable scientific probability inspired by the "more likely than not" principle. It is worth noting that in 2017 a judgement of the European Court of Justice in Luxembourg allowed courts to decide that a vaccine had caused harm, taking into account the "serious, specific, and consistent" presumptions of a causal relationship, even when there is no certain proof based on medical research to support this ${ }^{178}$. The presumptions include the time frame between vaccination and the evidence of disease, a lack of family history of the disease, and a considerable number of instances of the disease appearing, after administration of the vaccine.

A third series of considerations concerns legislation in which a vaccination obligation is being imposed. Clearly, this imposition implies a small but not absent risk of adverse events. In certain high-risk groups, such as immunocompromised patients and those with a history of previous anaphylactic reaction to a vaccine or its components, selective withholding of immunizations must be considered to decrease potential adverse 
events. However, aside from the case of primary immunodeficiency and some rare metabolic disease, till now there has been no routine laboratory test available with sufficient predictivity power to detect an increased risk of adverse reactions at the individual level. In this situation, a cautionary criterion should be adopted for all cases in which the existence of susceptibility factors is suspected, such as for example: a) family pathobiographic history, i.e. the previous occurrence of serious adverse reactions in family members, even without managing to make a molecular diagnosis, or b) genetic variation in a precise sense, determined by some already known specific polymorphism (see Table 1). It seems reasonable that, if a child presents with an increased risk of adverse reactions compared to the average risk of the population, for this subject the vaccination obligation should be "loose" and the choice of whether to vaccinate (taking the risk of AEFI) or not to vaccinate (taking the risk of any illness to which the subjects are unprotected) should be left to the doctor, in agreement with the parents. A corollary of this problem indicates that in order to improve risk assessment, studies on genetic predispositions to vaccine damage should be increased by establishing systematic analysis programs for polymorphisms, to be carried out from birth. The more subjects that are entered in these databases, after years of accumulating cases and comparing healthy and damaged subjects, the more precise the calculation of the relative risk associated with vaccinations will be. As knowledge of vaccinomics and adversomics increases, this estimate will be an increasingly precise element in decision-making in the coming years.

Adverse reactions associated with the vaccine and immunizationrelated error events can affect healthy individuals and should be promptly identified to decide whether and how to compensate those affected. We must reiterate the need not to confuse the epidemiological and individual perspectives: one being the risk/benefit of vaccination, another is the recognition (and possible compensation) of a causal-link association between an adverse event and the vaccine. The fact that a child carries a heightened risk of vaccination, does not mean that he/she should not be vaccinated. The risk/benefit ratio must be weighed on an individual level with care and precision, especially considering the incidence and severity of diseases to which they would be exposed if unvaccinated. On the other hand, it is correct that damaged individuals - perhaps even those who just "probably" have suffered serious harm from vaccination - are recognized and compensated. This way of proceeding should also serve to increase the general confidence of the population in vaccinations and reduce litigation in the health care system.

\section{Data availability}

No data are associated with this article.
1. WHO: Causality assessment of an adverse event following immunization (AEFI): user manual for the revised WHO classification (Second edition). 2nd Edition, Geneva, World Health Organization. 2018. Reference Source

2. Freckelton I: Vaccination Litigation: The Need for Rethinking Compensation for Victims of Vaccination Injury. J Law Med. 2018; 25(2): 293-314. PubMed Abstract

3. Meissner HC, Nair N, Plotkin SA: The National Vaccine Injury Compensation Program: Striking a Balance Between Individual Rights and Community Benefit. JAMA. 2019; 321(4): 343-344. PubMed Abstract | Publisher Full Text

4. Milon A, Bouvet R: Scientific Uncertainty in Courts. A France-Germany Comparative Perspective on Litigation surrounding Hepatitis B Vaccination. Eur J Health Law. 2019; 26(1): 5-25. PubMed Abstract | Publisher Full Text

5. Editorial: Laws are not the only way to boost immunization. Nature. 2018; 553(7688): 249-250.

PubMed Abstract | Publisher Full Text

6. Mainzer K: Thinking in Complexity. The Complex Dynamics of Matter, Mind, and Mankind. Berlin-Heidelberg, Springer-Verlag, 1994. Publisher Full Text

7. Schubert C, Lambertz M, Nelesen RA, et al:: Effects of stress on heart rate complexity--a comparison between short-term and chronic stress. Biol Psychol. 2009; 80(3): 325-332.

PubMed Abstract | Publisher Full Text | Free Full Text

8. Bolker BM, Grenfell BT: Chaos and biological complexity in measles dynamics. Proc Biol Sci. 1993; 251(1330): 75-81. PubMed Abstract | Publisher Full Tex

9. Heesterbeek $\mathrm{H}$, Anderson RM, Andreasen V, et al.: Modeling infectious disease dynamics in the complex landscape of global health. Science. 2015; 347(6227): aaa4339.

PubMed Abstract | Publisher Full Text | Free Full Text

10. Smith SW, Hauben M, Aronson JK: Paradoxical and bidirectional drug effects Drug Saf. 2012; 35(3): 173-189. PubMed Abstract | Publisher Full Text
11. Mann-Salinas LE, Engebretson J, Batchinsky Al: A complex systems view of sepsis: implications for nursing. Dimens Crit Care Nurs. 2013; 32(1): 12-17. PubMed Abstract | Publisher Full Text

12. Jones RM: Complexity and forensic pathology. Forensic Sci Int. 2015; 257 e38-e43.

PubMed Abstract | Publisher Full Text

13. Marx J: Unraveling the causes of diabetes. Science. 2002; 296(5568): 686-689. PubMed Abstract | Publisher Full Text

14. Marshall E: Lupus: mysterious disease holds its secrets tight. Science. 2002; 296(5568): 689-691.

PubMed Abstract | Publisher Full Text

15. Sawa A, Snyder SH: Schizophrenia: diverse approaches to a complex disease. Science. 2002; 296(5568): 692-695. PubMed Abstract | Publisher Full Text

16. Colafrancesco S, Agmon-Levin N, Perricone C, et al:: Unraveling the soul of autoimmune diseases: pathogenesis, diagnosis and treatment adding dowels to the puzzle. Immunol Res. 2013; 56(2-3): 200-205. PubMed Abstract | Publisher Full Text

17. McGarvey PB, Suzek BE, Baraniuk JN, et al:: In silico analysis of autoimmune diseases and genetic relationships to vaccination against infectious diseases. BMC Immunol. 2014; 15: 61 .

PubMed Abstract | Publisher Full Text | Free Full Text

18. Whitaker JA, Ovsyannikova IG, Poland GA: Adversomics: a new paradigm for vaccine safety and design. Expert Rev Vaccines. 2015; 14(7): 935-947. PubMed Abstract | Publisher Full Text | Free Full Text

19. Poland GA, Kennedy RB, McKinney BA, et al.: Vaccinomics, adversomics, and the immune response network theory: Individualized vaccinology in the 21st century. Semin Immunol. 2013; 25(2): 89-103. PubMed Abstract | Publisher Full Text | Free Full Text

20. Hagan T, Pulendran B: Will Systems Biology Deliver Its Promise and Contribute to the Development of New or Improved Vaccines? From Data to Understanding through Systems Biology. Cold Spring Harb Perspect Biol. 2018; 10(8): pii: a028894.

PubMed Abstract | Publisher Full Text | Free Full Text

21. Haralambieva IH, Kennedy RB, Ovsyannikova IG, et al:: Current perspectives in 
assessing humoral immunity after measles vaccination. Expert Rev Vaccines. 2019; 18(1): 75-87.

PubMed Abstract | Publisher Full Text | Free Full Text

22. Sharma M, Krammer F, Garcia-Sastre A, et al.: Moving from Empirical to Rational Vaccine Design in the 'Omics' Era. Vaccines (Basel). 2019; 7(3): pii: E89. PubMed Abstract | Publisher Full Text | Free Full Text

23. Gul A: Dynamics of Inflammatory Response in Autoinflammatory Disorders: Autonomous and Hyperinflammatory States. Front Immunol. 2018; 9: 2422. PubMed Abstract | Publisher Full Text | Free Full Text

24. Spadaro S, Park M, Turrini C, et al:: Biomarkers for Acute Respiratory Distress syndrome and prospects for personalised medicine. J Inflamm (Lond). 2019; 16: 1. PubMed Abstract | Publisher Full Text | Free Full Text

25. Stefanizzi P, Stella P, Ancona D, et al:: Adverse Events Following MeaslesMumps-Rubella-Varicella Vaccination and the Case of Seizures: A Post Marketing Active Surveillance in Puglia Italian Region, 2017-2018. Vaccines (Basel). 2019; 7(4): pii: E140.

PubMed Abstract | Publisher Full Text | Free Full Text

26. Nakayama T: An inflammatory response is essential for the development of adaptive immunity-immunogenicity and immunotoxicity. Vaccine. 2016; 34(47) 5815-5818.

PubMed Abstract | Publisher Full Text

27. Rock MT, Yoder SM, Talbot TR, et al:: Adverse events after smallpox immunizations are associated with alterations in systemic cytokine levels. $J$ Infect Dis. 2004; 189(8): 1401-1410.

PubMed Abstract | Publisher Full Text

28. McKinney BA, Reif DM, Rock MT, et al:: Cytokine expression patterns associated with systemic adverse events following smallpox immunization. $J$ Infect Dis. 2006; 194(4): 444-453.

PubMed Abstract | Publisher Full Text | Free Full Text

29. Bae HG, Domingo C, Tenorio A, et al:: Immune response during adverse events after 17D-derived yellow fever vaccination in Europe. J Infect Dis. 2008; 197(11): 1577-1584.

PubMed Abstract | Publisher Full Text

30. Demicheli V, Rivetti A, Debalini MG, et al.: Vaccines for measles, mumps and rubella in children. Cochrane Database Syst Rev. 2012; (2): CD004407. PubMed Abstract | Publisher Full Text | Free Full Text

31. Lee HG, Bae HB, Choi Jl, et al.: Febrile convulsions during recovery after anesthesia in an infant with history of MMR vaccination: A case report. Medicine (Baltimore). 2019; 98(35): e17047. PubMed Abstract | Publisher Full Text | Free Full Text

32. Ma SJ, Xiong $Y Q$, Jiang LN, et al:: Risk of febrile seizure after measles-mumpsrubella-varicella vaccine: A systematic review and meta-analysis. Vaccine. 2015; 33(31): 3636-3649

PubMed Abstract | Publisher Full Text

33. Huang WT, Gargiullo PM, Broder KR, et al:: Lack of association between acellular pertussis vaccine and seizures in early childhood. Pediatrics. 2010; 126(2): 263-269.

PubMed Abstract | Publisher Full Text

34. Barlow WE, Davis RL, Glasser JW, et al:: The risk of seizures after receipt of whole-cell pertussis or measles, mumps, and rubella vaccine. $N$ Engl J Med. 2001; 345(9): 656-661.

PubMed Abstract | Publisher Full Tex

35. Patel $A D$, Vidaurre $\mathrm{J}$ : Complex febrile seizures: a practical guide to evaluation and treatment. J Child Neurol. 2013; 28(6): 762-767.

PubMed Abstract | Publisher Full Text

36. Vestergaard M, Pedersen MG, Ostergaard JR, et al:: Death in children with febrile seizures: a population-based cohort study. Lancet. 2008; 372(9637): 457-463. PubMed Abstract | Publisher Full Text

37. Chungath M, Shorvon S: The mortality and morbidity of febrile seizures. Nat Clin Pract Neurol. 2008; 4(11): 610-621. PubMed Abstract | Publisher Full Text

38. Hefti MM, Kinney HC, Cryan JB, et al.: Sudden unexpected death in early childhood: general observations in a series of 151 cases: Part 1 of the investigations of the San Diego SUDC Research Project. Forensic Sci Med Pathol. 2016; 12(1): 4-13.

PubMed Abstract | Publisher Full Text | Free Full Text

39. Dlouhy BJ, Ciliberto MA, Cifra CL, et al.: Unexpected Death of a Child with Complex Febrile Seizures-Pathophysiology Similar to Sudden Unexpected Death in Epilepsy? Front Neurol. 2017; 8: 21.

PubMed Abstract | Publisher Full Text | Free Full Text

40. Crandall LG, Lee JH, Stainman R, et al:: Potential Role of Febrile Seizures and Other Risk Factors Associated With Sudden Deaths in Children. JAMA Netw Open. 2019; 2(4): e192739.

PubMed Abstract | Publisher Full Text | Free Full Text

41. Pujar SS, Martinos MM, Cortina-Borja M, et al.: Long-term prognosis after childhood convulsive status epilepticus: a prospective cohort study. Lancet Child Adolesc Health. 2018; 2(2): 103-111.

PubMed Abstract | Publisher Full Text

42. Gentili G, D'Amelio R, Wirz M, et al: Prevalence of hyperimmunization against tetanus in Italians born after the introduction of mandatory vaccination of children with tetanus toxoid in 1968. Infection. 1993; 21(2): 80-82. PubMed Abstract | Publisher Full Text

43. Barbaud A, Deschildre A, Waton J, et al:: Hypersensitivity and vaccines: an update. Eur J Dermatol. 2013; 23(2): 135-141

PubMed Abstract | Publisher Full Text

44. Watanabe T: Vasculitis Following Influenza Vaccination: A Review of the Literature. Curr Rheumatol Rev. 2017; 13(3):188-196.

PubMed Abstract | Publisher Full Text

45. de la Fuente IG, Wagner N, Siegrist CA, et al.: Tetanus immunity as a surrogate for past diphtheria-tetanus-pertussis immunization in migrant children. Pediatr Infect Dis J. 2013; 32(3): 274-277.

PubMed Abstract | Publisher Full Text

46. Toussirot É, Bereau M: Vaccination and Induction of Autoimmune Diseases. Inflamm Allergy Drug Targets. 2015; 14(2): 94-98.

PubMed Abstract | Publisher Full Text

47. Zafrir $\mathrm{Y}$, Agmon-Levin N, Paz Z, et al.: Autoimmunity following hepatitis $B$ vaccine as part of the spectrum of 'Autoimmune (Auto-inflammatory) Syndrome induced by Adjuvants' (ASIA): analysis of 93 cases. Lupus. 2012; 21(2): 146-152. PubMed Abstract | Publisher Full Text

48. Perricone C, Colafrancesco S, Mazor RD, et al:: Autoimmune/inflammatory syndrome induced by adjuvants (ASIA) 2013: Unveiling the pathogenic, clinical and diagnostic aspects. J Autoimmun. 2013; 47: 1-16.

PubMed Abstract | Publisher Full Text

49. Perricone C, Ceccarelli F, Nesher G, et al.: Immune thrombocytopenic purpura (ITP) associated with vaccinations: a review of reported cases. Immunol Res. 2014; 60(2-3): 226-235. PubMed Abstract | Publisher Full Text

50. Agmon-Levin N, Arango MT, Kivity S, et al.: Immunization with hepatitis B vaccine accelerates SLE-like disease in a murine model. J Autoimmun. 2014; 54: 21-32.

PubMed Abstract | Publisher Full Text

51. Colafrancesco S, Perricone C, Priori R, et al:: Sjögren's syndrome: another facet of the autoimmune/inflammatory syndrome induced by adjuvants (ASIA). $J$ Autoimmun. 2014; 51: 10-16.

PubMed Abstract | Publisher Full Text

52. Rinaldi M, Perricone C, Ortega-Hernandez OD, et al:: Immune thrombocytopaenic purpura: an autoimmune cross-link between infections and vaccines. Lupus. 2014; 23(6): 554-567.

PubMed Abstract | Publisher Full Text

53. Guimarães LE, Baker B, Perricone C, et al:: Vaccines, adjuvants and autoimmunity. Pharmacol Res. 2015; 100: 190-209. PubMed Abstract | Publisher Full Text

54. Baker B, Eça Guimarães L, Tomljenovic L, et al:: The safety of human papilloma virus-blockers and the risk of triggering autoimmune diseases. Expert Opin Drug Saf. 2015; 14(9): 1387-1394. PubMed Abstract | Publisher Full Text

55. Haase $\mathrm{H}$, Hebel $\mathrm{S}$, Engelhardt $\mathrm{G}$, et al:: Ethylmercury and $\mathrm{Hg}^{2+}$ induce the formation of neutrophil extracellular traps (NETs) by human neutrophil granulocytes. Arch Toxicol. 2016; 90(3): 543-550.

PubMed Abstract | Publisher Full Text

56. Cerpa-Cruz $\mathrm{S}$, Paredes-Casillas $\mathrm{P}$, Landeros Navarro E, et al.: Adverse events following immunization with vaccines containing adjuvants. Immunol Res. 2013; 56(2-3): 299-303.

PubMed Abstract | Publisher Full Text

57. Ruhrman-Shahar N, Torres-Ruiz J, Rotman-Pikielny P, et al:: Autoimmune reaction after anti-tetanus vaccination-description of four cases and review of the literature. Immunol Res. 2017; 65(1): 157-163. PubMed Abstract | Publisher Full Text

58. De MM, Chiappini E, Galli L: Vaccines and autoimmunity. Int J Immunopathol Pharmacol. 2013; 26(2): 283-290. PubMed Abstract | Publisher Full Text

59. Cruz-Tapias P, Blank M, Anaya JM, et al.: Infections and vaccines in the etiology of antiphospholipid syndrome. Curr Opin Rheumatol. 2012; 24(4): 389-393. PubMed Abstract | Publisher Full Text

60. Israeli E, Agmon-Levin N, Blank M, et al.: Guillain-Barré syndrome--a classical autoimmune disease triggered by infection or vaccination. Clin Rev Allergy Immunol. 2012; 42(2): 121-130.

PubMed Abstract | Publisher Full Text

61. Shoenfeld $\mathrm{Y}$, Agmon-Levin N: 'ASIA' - autoimmune/inflammatory syndrome induced by adjuvants. $J$ Autoimmun. 2011; 36(1): 4-8 PubMed Abstract | Publisher Full Text

62. Watad A, Quaresma M, Brown S, et al: Autoimmune/inflammatory syndrome induced by adjuvants (Shoenfeld's syndrome) - An update. Lupus. 2017; 26(7): $675-681$

PubMed Abstract | Publisher Full Text

63. Watad A, Quaresma M, Bragazzi NL, et al:: The autoimmune/inflammatory syndrome induced by adjuvants (ASIA)/Shoenfeld's syndrome: descriptive analysis of $\mathbf{3 0 0}$ patients from the international ASIA syndrome registry. Clin Rheumatol. 2018; 37(2): 483-493. PubMed Abstract | Publisher Full Text

64. Bragazzi NL, Watad A, Sharif $\mathrm{K}$, et al:: Advances in our understanding of immunization and vaccines for patients with systemic lupus erythematosus. Expert Rev Clin Immunol. 2017; 13(10): 939-949. PubMed Abstract | Publisher Full Text

65. Wang $B$, Shao X, Wang D, et al.: Vaccinations and risk of systemic lupus 
erythematosus and rheumatoid arthritis: A systematic review and metaanalysis. Autoimmun Rev. 2017; 16(7): 756-765.

PubMed Abstract | Publisher Full Text

66. Segal $\mathrm{Y}$, Calabrò M, Kanduc D, et al.: Human papilloma virus and lupus: the virus, the vaccine and the disease. Curr Opin Rheumatol. 2017; 29(4): 331-342. PubMed Abstract | Publisher Full Text

67. Qiu CC, Caricchio R, Gallucci S: Triggers of Autoimmunity: The Role of Bacterial Infections in the Extracellular Exposure of Lupus Nuclear Autoantigens. Front Immunol. 2019; 10: 2608 .

PubMed Abstract | Publisher Full Text | Free Full Text

68. Szczech J, Samotij D, Werth VP, et al:: Trigger factors of cutaneous lupus erythematosus: a review of current literature. Lupus. 2017: 26(8): 791-807. PubMed Abstract | Publisher Full Text

69. Molineros JE, Looger LL, Kim K, et al:: Amino acid signatures of HLA Class-I and II molecules are strongly associated with SLE susceptibility and autoantibody production in Eastern Asians. PLoS Genet. 2019; 15(4): e1008092. PubMed Abstract | Publisher Full Text | Free Full Text

70. Santoro D, Vita G, Vita R, et al.: HLA haplotype in a patient with systemic lupus erythematosus triggered by hepatitis B vaccine. Clin Nephrol. 2010; 74(2): 150-153.

PubMed Abstract | Publisher Full Text

71. Nusbaum JS, Mirza I, Shum J, et al:: Sex Differences in Systemic Lupus Erythematosus: Epidemiology, Clinical Considerations, and Disease Pathogenesis. Mayo Clin Proc. 2020; 95(2): 384-394.

PubMed Abstract | Publisher Full Text

72. Kanduc D, Shoenfeld Y: From HBV to HPV: Designing vaccines for extensive and intensive vaccination campaigns worldwide. Autoimmun Rev. 2016; 15(11) 1054-1061.

PubMed Abstract | Publisher Full Text

73. Bragazzi NL, Bridgewood C, Sharif K, et al:: HPV vaccines and lupus: current approaches towards preventing adverse immune cross-reactivity. Expert Rev Vaccines. 2019; 18(1): 31-42.

PubMed Abstract | Publisher Full Text

74. Krewski D, Yokel RA, Nieboer E, et al.: Human health risk assessment for aluminium, aluminium oxide, and aluminium hydroxide. $J$ Toxicol Environ Health B Crit Rev. 2007; 10(Suppl 1): 1-269.

PubMed Abstract | Publisher Full Text | Free Full Text

75. Shaw CA, Li D, Tomljenovic L: Are there negative CNS impacts of aluminum adjuvants used in vaccines and immunotherapy? Immunotherapy. 2014; 6(10): 1055-1071.

PubMed Abstract | Publisher Full Text

76. Shaw CA, Seneff S, Kette SD, et al:: Aluminum-induced entropy in biological systems: implications for neurological disease. J Toxicol. 2014; 2014: 491316. PubMed Abstract | Publisher Full Text | Free Full Text

77. Willhite CC, Karyakina NA, Yokel RA, et al: Systematic review of potential health risks posed by pharmaceutical, occupational and consumer exposures to metallic and nanoscale aluminum, aluminum oxides, aluminum hydroxide and its soluble salts. Crit Rev Toxicol. 2014; 44(Suppl 4): 1-80. PubMed Abstract | Publisher Full Text | Free Full Text

78. Mold M, Shardlow E, Exley C: Insight into the cellular fate and toxicity of aluminium adjuvants used in clinically approved human vaccinations. Sci Rep. 2016; 6: 31578.

PubMed Abstract | Publisher Full Text | Free Full Text

79. Gherardi RK, Aouizerate J, Cadusseau J, et al: : Aluminum adjuvants of vaccines injected into the muscle: Normal fate, pathology and associated disease. Morphologie. 2016; 100(329): 85-94.

PubMed Abstract | Publisher Full Text

80. Maya S, Prakash T, Madhu KD, et al:: Multifaceted effects of aluminium in neurodegenerative diseases: A review. Biomed Pharmacother. 2016: 83: 746-754. PubMed Abstract | Publisher Full Text

81. Shardlow E, Mold M, Exley C: The interaction of aluminium-based adjuvants with THP-1 macrophages in vitro: Implications for cellular survival and systemic translocation. J Inorg Biochem. 2020; 203: 110915. PubMed Abstract | Publisher Full Text

82. Exley $\mathrm{C}$ : An aluminium adjuvant in a vaccine is an acute exposure to aluminium. J Trace Elem Med Biol. 2020; 57: 57-59. PubMed Abstract | Publisher Full Text

83. Shaw CA, Li Y, Tomljenovic L: Administration of aluminium to neonatal mice in vaccine-relevant amounts is associated with adverse long term neurological outcomes. J Inorg Biochem. 2013; 128: 237-244.

PubMed Abstract | Publisher Full Text

84. Crepeaux G, Eidi H, David MO, et al.: Non-linear dose-response of aluminium hydroxide adjuvant particles: Selective low dose neurotoxicity. Toxicology. 2017; 375: 48-57.

PubMed Abstract | Publisher Full Text

85. Gherardi RK, Coquet $\mathrm{M}$, Cherin $\mathrm{P}$, et al.: Macrophagic myofasciitis lesions assess long-term persistence of vaccine-derived aluminium hydroxide in muscle. Brain. 2001; 124(Pt 9): 1821-1831. PubMed Abstract | Publisher Full Text

86. Rigolet $\mathrm{M}$, Aouizerate $\mathrm{J}$, Couette $\mathrm{M}$, et al:: Clinical features in patients with longlasting macrophagic myofasciitis. Front Neurol. 2014; 5: 230. PubMed Abstract | Publisher Full Text | Free Full Text

87. Bonnefont-Rousselot D, Chantalat-Auger C, Teixeira A, et al:: Blood oxidative stress status in patients with macrophagic myofasciitis. Biomed Pharmacother. 2004; 58(9): 516-519.

PubMed Abstract | Publisher Full Text

88. Ragunathan-Thangarajah N, Le Beller C, Boutouyrie $\mathrm{P}$, et al.: Distinctive clinical features in arthro-myalgic patients with and without aluminum hydroxydeinduced macrophagic myofasciitis: an exploratory study. $J$ Inorg Biochem. 2013; 128: 262-266.

PubMed Abstract | Publisher Full Text

89. Passeri E, Villa C, Couette M, et al:: Long-term follow-up of cognitive dysfunction in patients with aluminum hydroxide-induced macrophagic myofasciitis (MMF). $J$ Inorg Biochem. 2011; 105(11): 1457-1463.

PubMed Abstract | Publisher Full Text

90. Exley C, Swarbrick L, Gherardi RK, et al:: A role for the body burden of aluminium in vaccine-associated macrophagic myofasciitis and chronic fatigue syndrome. Med Hypotheses. 2009; 72(2): 135-139.

PubMed Abstract | Publisher Full Text

91. Santiago T, Rebelo O, Negrao L, et al:: Macrophagic myofasciitis and vaccination: consequence or coincidence? Rheumatol Int. 2015; 35(1): 189-192. PubMed Abstract | Publisher Full Text

92. Muller HD, Landeghem FK, Schmidt PF, et al:: Macrophagic myofasciitis plus (distinct types of muscular dystrophy). Neuropediatrics. 2009; 40(4): 174-178. PubMed Abstract | Publisher Full Text

93. Gruis KL, Teener JW, Blaivas M: Pediatric macrophagic myofasciitis associated with motor delay. Clin Neuropathol. 2006; 25(4): 172-179. PubMed Abstract

94. Authier FJ, Cherin P, Creange A, et al:: Central nervous system disease in patients with macrophagic myofasciitis. Brain. 2001; 124(Pt 5): 974-983. PubMed Abstract | Publisher Full Text

95. Van Der Gucht A, Aoun Sebaiti M, Itti E, et al:: Neuropsychological Correlates of Brain Perfusion SPECT in Patients with Macrophagic Myofasciitis. PLOS One. 2015; 10(6): e0128353.

PubMed Abstract | Publisher Full Text | Free Full Text

96. Morris G, Puri BK, Frye RE: The putative role of environmental aluminium in the development of chronic neuropathology in adults and children. How strong is the evidence and what could be the mechanisms involved? Metab Brain Dis. 2017; 32(5): 1335-1355.

PubMed Abstract | Publisher Full Text | Free Full Text

97. Shaghaghi M, Soleyman-Jahi S, Abolhassani $\mathrm{H}$, et al:: New insights into physiopathology of immunodeficiency-associated vaccine-derived poliovirus infection; systematic review of over 5 decades of data. Vaccine. 2018; 36(13): 1711-1719.

PubMed Abstract | Publisher Full Text

98. Bakare N, Menschik D, Tiernan R, et al:: Severe combined immunodeficiency (SCID) and rotavirus vaccination: reports to the Vaccine Adverse Events Reporting System (VAERS). Vaccine. 2010; 28(40): 6609-6612.

PubMed Abstract | Publisher Full Text

99. Bogaert D, Van Schil K, Taghon T, et al.: Persistent rotavirus diarrhea posttransplant in a novel JAK3-SCID patient after vaccination. Pediatr Allergy Immunol. 2016; 27(1): 93-96.

PubMed Abstract | Publisher Full Text

100. Chiu M, Bao C, Sadarangani M: Dilemmas With Rotavirus Vaccine: The Neonate and Immunocompromised. Pediatr Infect Dis J. 2019; 38(6S Suppl 1): S43-S46. PubMed Abstract | Publisher Full Text

101. Bonilla FA: Update: Vaccines in primary immunodeficiency. J Allergy Clin Immunol. 2018; 141(2): 474-481.

PubMed Abstract | Publisher Full Text

102. Fekrvand $S$, Yazdani R, Olbrich $P$, et al.: Primary Immunodeficiency Diseases and Bacillus Calmette-Guérin (BCG)-Vaccine-Derived Complications: A Systematic Review. J Allergy Clin Immunol Pract. 2020; pii: S2213-2198(20)30096-9. PubMed Abstract | Publisher Full Text

103. Bitnun A, Shannon $P$, Durward A, et al.: Measles inclusion-body encephalitis caused by the vaccine strain of measles virus. Clin Infect Dis. 1999; 29(4): 855-861.

PubMed Abstract | Publisher Full Text

104. Poyhonen L, Nuolivirta K, Vuononvirta J, et al:: Toll-like receptor 2 subfamily gene polymorphisms are associated with Bacillus Calmette-Guerin osteitis following newborn vaccination. Acta Paediatr. 2015; 104(5): 485-490. PubMed Abstract | Publisher Full Text

105. Poyhonen L, Kroger L, Huhtala H, et al:: Association of MBL2, TLR1, TLR2 and TLR6 Polymorphisms With Production of IFN- $\gamma$ and IL-12 in BCG Osteitis Survivors R1. Pediatr Infect Dis J. 2017; 36(2): 135-139. PubMed Abstract | Publisher Full Text

106. Hassanzad M, Farnia $P$, Darougar $S$, et al.: A novel evaluation of genetic polymorphism in BCG adenitis. Turk J Pediatr. 2019; 61(3): 466-470. PubMed Abstract | Publisher Full Text

107. Korppi M, Terasjarvi J, Liehu-Martiskainen M, et al:: Haplotype of the Interleukin $17 \mathrm{~A}$ gene is associated with osteitis after Bacillus Calmette-Guerin vaccination. Sci Rep. 2017; 7(1): 11691. PubMed Abstract | Publisher Full Text | Free Full Text

108. Reif DM, McKinney BA, Motsinger AA, et al.: Genetic basis for adverse events after smallpox vaccination. J Infect Dis. 2008; 198(1): 16-22. PubMed Abstract | Publisher Full Text | Free Full Text

109. Stanley SL Jr, Frey SE, Taillon-Miller $P$, et al:: The immunogenetics of smallpox 
vaccination. J Infect Dis. 2007; 196(2): 212-219.

PubMed Abstract | Publisher Full Text

110. Ovsyannikova IG, Haralambieva IH, Kennedy RB, et al.: Impact of cytokine and cytokine receptor gene polymorphisms on cellular immunity after smallpox vaccination. Gene. 2012; 510(1): 59-65.

PubMed Abstract | Publisher Full Text | Free Full Text

111. Reif DM, Motsinger-Reif AA, McKinney BA, et al:: Integrated analysis of genetic and proteomic data identifies biomarkers associated with adverse events following smallpox vaccination. Genes Immun. 2009; 10(2): 112-119. PubMed Abstract | Publisher Full Text | Free Full Text

112. Berkovic SF, Harkin L, McMahon JM, et al:: De-novo mutations of the sodium channel gene SCN1A in alleged vaccine encephalopathy: a retrospective study. Lancet Neurol. 2006; 5(6): 488-492. PubMed Abstract | Publisher Full Text

113. Huynh W, Cordato DJ, Kehdi E, et al.: Post-vaccination encephalomyelitis: literature review and illustrative case. J Clin Neurosci. 2008; 15(12): 1315-1322. PubMed Abstract | Publisher Full Text

114. Verbeek NE, Van Der Maas NA, Jansen FE, et al.: Prevalence of SCN1A-related dravet syndrome among children reported with seizures following vaccination: a population-based ten-year cohort study. PLoS One. 2013; 8(6): e65758. PubMed Abstract | Publisher Full Text | Free Full Text

115. Kwong AK, Fung CW, Chan SY, et al:: Identification of SCN1A and PCDH19 mutations in Chinese children with Dravet syndrome. PLOS One. 2012; 7(7): e41802.

PubMed Abstract | Publisher Full Text | Free Full Text

116. Verbeek NE, Van Der Maas NA, Sonsma AC, et al.: Effect of vaccinations on seizure risk and disease course in Dravet syndrome. Neurology. 2015; 85(7): 596-603.

PubMed Abstract | Publisher Full Text

117. Mukherjee D, Mukherjee S, Niyogi P, et al.: Dravet syndrome with SCN1B gene mutation: A rare entity. Neurol India. 2017; 65(4): 801-803. PubMed Abstract | Publisher Full Text

118. Feenstra B, Pasternak B, Geller F, et al.: Common variants associated with general and MMR vaccine-related febrile seizures. Nat Genet. 2014; 46(12): 1274-1282.

PubMed Abstract | Publisher Full Text | Free Full Text

119. Fazeli W, Becker K, Herkenrath P, et al:: Dominant SCN2A Mutation Cause Familial Episodic Ataxia and Impairment of Speech Development. Neuropediatrics. 2018; 49(6): 379-384. PubMed Abstract | Publisher Full Text

120. Cohen Jl: Herpesviruses in the Activated Phosphatidylinositol-3-Kinase- $\delta$ Syndrome.. Front Immunol. 2018; 9: 237. PubMed Abstract | Publisher Full Text | Free Full Text

121. Bayer DK, Martinez CA, Sorte HS, et al.: Vaccine-associated varicella and rubella infections in severe combined immunodeficiency with isolated CD4 lymphocytopenia and mutations in IL7R detected by tandem whole exome sequencing and chromosomal microarray. Clin Exp Immunol. 2014; 178(3): 459-469.

PubMed Abstract | Publisher Full Text | Free Full Text

122. Pulendran B, Miller J, Querec TD, et al: Case of yellow fever vaccine--associated viscerotropic disease with prolonged viremia, robust adaptive immune responses, and polymorphisms in CCR5 and RANTES genes. J Infect Dis. 2008; 198(4): 500-507.

PubMed Abstract | Publisher Full Text | Free Full Text

123. Bomfim IL, Lamb F, Fink $\mathrm{K}$, et al:: The immunogenetics of narcolepsy associated with $A(H 1 N 1) p d m 09$ vaccination (Pandemrix) supports a potent geneenvironment interaction. Genes Immun. 2017; 18(2): 75-81. PubMed Abstract | Publisher Full Text

124. Hallberg $\mathrm{P}$, Smedje $\mathrm{H}$, Eriksson $\mathrm{N}$, et al.: Pandemrix-induced narcolepsy is associated with genes related to immunity and neuronal survival. EBioMedicine. 2019; 40: 595-604. PubMed Abstract | Publisher Full Text | Free Full Text

125. Israeli $\mathrm{E}$, Agmon-Levin $\mathrm{N}$, Blank $\mathrm{M}$, et al:: Macrophagic myofaciitis a vaccin (alum) autoimmune-related disease. Clin Rev Allergy Immunol. 2011; 41(2): 163-168.

PubMed Abstract | Publisher Full Text

126. Miller JD, Whitehair LH: Concurrent HLA-related response factors mediate recombinant hepatitis B vaccine major adverse events. Autoimmunity. 2005; 38(2): 181-194.

PubMed Abstract | Publisher Full Text

127. Arango MT, Perricone C, Kivity S, et al.: HLA-DRB1 the notorious gene in the mosaic of autoimmunity. Immunol Res. 2017; 65(1): 82-98. PubMed Abstract | Publisher Full Text

128. Kingsley JD, Varman M, Chatterjee A, et al.: Immunizations for patients with metabolic disorders. Pediatrics. 2006; 118(2): e460-e470. PubMed Abstract | Publisher Full Text

129. Nakayama J, Arinami T: Molecular genetics of febrile seizures. Epilepsy Res. 2006; 70 Suppl 1: S190-S198. PubMed Abstract | Publisher Full Text

130. Nur BG, Kahramaner Z, Duman O, et al:: Interleukin-6 gene polymorphism in febrile seizures. Pediatr Neurol. 2012; 46(1): 36-38. PubMed Abstract | Publisher Full Text

131. Vestergaard M, Hviid A, Madsen KM, et al:: MMR vaccination and febrile seizures: evaluation of susceptible subgroups and long-term prognosis.
JAMA. 2004; 292(3): 351-357.

PubMed Abstract | Publisher Full Text

132. Gvozdenovic E, Vetter V, Willame C, et al.: Impact of history of febrile convulsions on the risk difference of febrile convulsions with the tetravalent measles-mumps-rubella-varicella vaccine: Post-hoc exploratory analysis of results from a matched-cohort study. Vaccine. 2018; 36(39): 5803-5806. PubMed Abstract | Publisher Full Text

133. Haralambieva IH, Ovsyannikova IG, Kennedy RB, et al:: Genome-wide associations of CD46 and IFI44L genetic variants with neutralizing antibody response to measles vaccine. Hum Genet. 2017; 136(4): 421-435. PubMed Abstract | Publisher Full Text | Free Full Text

134. Scheffer IE: Diagnosis and long-term course of Dravet syndrome. Eur J Paediatr Neurol. 2012; 16(Suppl 1): S5-S8. PubMed Abstract | Publisher Full Text

135. Auvin S, Jeljeli M, Desnous $B$, et al.: Altered vaccine-induced immunity in children with Dravet syndrome. Epilepsia. 2018; 59(4): e45-e50. PubMed Abstract | Publisher Full Text

136. Verbeek NE, Jansen FE, Vermeer-de Bondt PE, et al.: Etiologies for seizures around the time of vaccination. Pediatrics. 2014; 134(4): 658-666. PubMed Abstract | Publisher Full Text

137. Azzari C, Gambineri E, Resti M, et al.: Safety and immunogenicity of measlesmumps-rubella vaccine in children with congenital immunodeficiency (DiGeorge syndrome). Vaccine. 2005; 23(14): 1668-1671. PubMed Abstract | Publisher Full Text

138. Lin $\mathrm{Y}, \mathrm{He} \mathrm{Y}$ : The ontology of genetic susceptibility factors (OGSF) and its application in modeling genetic susceptibility to vaccine adverse events. J Biomed Semantics. 2014; 5: 19

PubMed Abstract | Publisher Full Text | Free Full Text

139. He Y: Ontology-based Vaccine and Drug Adverse Event Representation and Theory-guided Systematic Causal Network Analysis toward Integrative Pharmacovigilance Research. Curr Pharmacol Rep. 2016; 2(3): 113-128. PubMed Abstract | Publisher Full Text | Free Full Text

140. Xie J, He Y: Ontology-Based Vaccine Adverse Event Representation and Analysis. Adv Exp Med Biol. 2017; 1028: 89-103. PubMed Abstract | Publisher Full Text

141. Henry CJ, Huang Y, Wynne A, et al:: Minocycline attenuates lipopolysaccharide (LPS)-induced neuroinflammation, sickness behavior, and anhedonia. J Neuroinflammation. 2008; 5: 15 . PubMed Abstract | Publisher Full Text | Free Full Text

142. Daulatzai MA: Chronic functional bowel syndrome enhances gut-brain axis dysfunction, neuroinflammation, cognitive impairment, and vulnerability to dementia. Neurochem Res. 2014; 39(4): 624-644. PubMed Abstract | Publisher Full Text

143. Brown GC: The endotoxin hypothesis of neurodegeneration. $J$ Neuroinflammation. 2019; 16(1): 180. PubMed Abstract | Publisher Full Text | Free Full Text

144. Gershwin LJ: Adverse Reactions to Vaccination: From Anaphylaxis to Autoimmunity.. Vet Clin North Am Small Anim Pract. 2018; 48(2): 279-290. PubMed Abstract | Publisher Full Text

145. Segal $Y$, Shoenfeld $Y$ : Vaccine-induced autoimmunity: the role of molecular mimicry and immune crossreaction. Cell Mol Immunol. 2018; 15(6): 586-594. PubMed Abstract | Publisher Full Text | Free Full Text

146. Lee SJ, Lee S: Toll-like receptors and inflammation in the CNS. Curr Drug Targets Inflamm Allergy. 2002; 1(2): 181-191. PubMed Abstract | Publisher Full Text

147. Suzumura A, Takeuchi $\mathrm{H}$, Zhang G, et al: Roles of glia-derived cytokines on neuronal degeneration and regeneration. Ann N Y Acad Sci. 2006; 1088: 219-229. PubMed Abstract | Publisher Full Text

148. Brambilla L, Martorana F, Rossi D: Astrocyte signaling and neurodegeneration: new insights into CNS disorders. Prion. 2013; 7(1): 28-36. PubMed Abstract | Publisher Full Text | Free Full Text

149. Dehner $\mathrm{C}$, Fine $\mathrm{R}$, Kriegel MA: The microbiome in systemic autoimmune disease: mechanistic insights from recent studies. Curr Opin Rheumatol. 2019; 31(2): 201-207 PubMed Abstract | Publisher Full Text | Free Full Text

150. Camara-Lemarroy CR, Metz LM, Yong VW: Focus on the gut-brain axis: Multiple sclerosis, the intestinal barrier and the microbiome. World J Gastroenterol. 2018; 24(37): 4217-4223. PubMed Abstract | Publisher Full Text | Free Full Text

151. Gholizadeh $\mathrm{P}$, Mahallei M, Pormohammad A, et al:: Microbial balance in the intestinal microbiota and its association with diabetes, obesity and allergic disease. Microb Pathog. 2019; 127: 48-55. PubMed Abstract | Publisher Full Text

152. Tozzi AE, Asturias EJ, Balakrishnan MR, et al:: Assessment of causality of individual adverse events following immunization (AEFI): a WHO tool for global use. Vaccine. 2013; 31(44): 5041-5046. PubMed Abstract | Publisher Full Text

153. Cosmacini G: Storia della medicina e della sanità in Italia. Bari, Laterza. 2010 Reference Source

154. Tourbah A, Gout O, Liblau R, et al.: Encephalitis after hepatitis B vaccination: recurrent disseminated encephalitis or MS? Neurology. 1999; 53(2): 396-401. PubMed Abstract | Publisher Full Text

155. Yuan JL, Wang SK, Guo XJ, et al.: Acute Disseminated Encephalomyelitis 
following Vaccination against Hepatitis B in a Child: A Case Report and Literature Review. Case Rep Neurol Med. 2016; 2016: 2401809. PubMed Abstract | Publisher Full Text | Free Full Text

156. Leslie DL, Kobre RA, Richmand BJ, et al:: Temporal Association of Certain Neuropsychiatric Disorders Following Vaccination of Children and Adolescents: A Pilot Case-Control Study. Front Psychiatry. 2017; 8: 3. PubMed Abstract | Publisher Full Text | Free Full Text

157. WHO: Causality assessment of an adverse event following immunization (AEFI): user manual for the revised WHO classification. Geneva. 2013. Reference Source

158. Puliyel J, Naik P: Revised World Health Organization (WHO)'s causality assessment of adverse events following immunization-a critique [version 2 ; peer review: 2 approved] F1000Res. 2018; 7: 243 . PubMed Abstract | Publisher Full Text | Free Full Text

159. Singh VK: Phenotypic expression of autoimmune autistic disorder (AAD): a major subset of autism. Ann Clin Psychiatry. 2009; 21(3): 148-161. PubMed Abstract

160. Shaw CA, Tomljenovic L: Aluminum in the central nervous system (CNS): toxicity in humans and animals, vaccine adjuvants, and autoimmunity. Immunol Res. 2013; 56(2-3): 304-316. PubMed Abstract | Publisher Full Text

161. Mostafa GA, Shehab AA, Al-Ayadhi LY: The link between some alleles on human leukocyte antigen system and autism in children. J Neuroimmunol. 2013; 255(1-2): 70-74. PubMed Abstract | Publisher Full Text

162. Edmiston E, Ashwood P, Van de Water J: Autoimmunity, Autoantibodies, and Autism Spectrum Disorder. Biol Psychiatry. 2017; 81(5): 383-390. PubMed Abstract | Publisher Full Text | Free Full Text

163. Hughes HK, Mills KE, Rose D, et al.: Immune Dysfunction and Autoimmunity as Pathological Mechanisms in Autism Spectrum Disorders. Front Cell Neurosci. 2018; 12: 405 PubMed Abstract | Publisher Full Text | Free Full Text

164. Gherardi RK, Crepeaux G, Authier FJ: Myalgia and chronic fatigue syndrome following immunization: macrophagic myofasciitis and animal studies suppor linkage to aluminum adjuvant persistency and diffusion in the immune system. Autoimmun Rev. 2019; 18(7): 691-705. PubMed Abstract | Publisher Full Text

165. Aoun Sebaiti SM, Abrivard M, Blanc-Durand P, et al.: Macrophagic myofasciitisassociated dysfunctioning: An update of neuropsychological and neuroimaging features. Best Pract Res Clin Rheumatol. 2018; 32(5): 640-650. PubMed Abstract | Publisher Full Text

166. Soares Santos D, Santos A, Rebelo O, et al.: Macrophagic myofasciitis: a challenging diagnosis. BMJ Case Rep. 2018; 2018: pii. bcr-2018-224602. PubMed Abstract | Publisher Full Text
167. Aoun Sebaiti M, Kauv P, Charles-Nelson A, et al.: Cognitive dysfunction associated with aluminum hydroxide-induced macrophagic myofasciitis: $A$ reappraisal of neuropsychological profile. J Inorg Biochem. 2018; 181: 132-138. PubMed Abstract | Publisher Full Text

168. Zinka B, Rauch E, Buettner A, et al.: Unexplained cases of sudden infant death shortly after hexavalent vaccination. Vaccine. 2006; 24(31-32): 5779-5780. PubMed Abstract | Publisher Full Text

169. Biru N, Shlobin OA, Aryal S, et al.: Rare Case of Rapidly Progressive Interstitial Lung Disease Following Adult Tetanus, Diptheria, and Pertussis (TDAP) Vaccination. Am J Resp Crit Care Med. 2018; 197: A6582. Reference Source

170. Hibino M, Kondo T: Interstitial Pneumonia Associated with the Influenza Vaccine: A Report of Two Cases. Intern Med. 2017; 56(2): 197-201. PubMed Abstract | Publisher Full Text | Free Full Text

171. Osawa M, Nagao R, Kakimoto $Y$, et al:: Sudden Infant Death After Vaccination: Survey of Forensic Autopsy Files. Am J Forensic Med Pathol. 2019; 40(3): $232-237$ PubMed Abstract | Publisher Full Text

172. Puliyel J, Phadke A: Deaths following pentavalent vaccine and the revised AEFI classification. Indian J Med Ethics. 2017; 2(4): 300-301. PubMed Abstract | Publisher Full Text

173. Gold MS, Balakrishnan MR, Amarasinghe A, et al: An approach to death as an adverse event following immunization. Vaccine. 2016; 34(2): 212-217. PubMed Abstract | Publisher Full Text

174. Becher JC, Keeling JW, Bell J, et al.: Apolipoprotein E e4 and its prevalence in early childhood death due to sudden infant death syndrome or to recognised causes. Early Hum Dev. 2008; 84(8): 549-554. PubMed Abstract | Publisher Full Text

175. Ball R, Halsey N, Braun MM, et al.: Development of case definitions for acute encephalopathy, encephalitis, and multiple sclerosis reports to the vaccine: Adverse Event Reporting System. J Clin Epidemiol. 2002; 55(8): 819-824. PubMed Abstract | Publisher Full Text

176. MacLennan JM, Shackley F, Heath PT, et al:: Safety, immunogenicity, and induction of immunologic memory by a serogroup $\mathrm{C}$ meningococcal conjugate vaccine in infants: A randomized controlled trial. JAMA. 2000; 283(21): 2795-2801. PubMed Abstract | Publisher Full Text

177. Ishidou M, Kanno K, Imai K, et al:: Novel Left Atrioventricular Valvuloplasty for Atrioventricular Septal Defect. Ann Thorac Surg. 2019; 107(4): e251-e253. PubMed Abstract | Publisher Full Text

178. Dyer C: Courts can decide that vaccine has caused harm despite lack of evidence. BMJ. 2017; 357: 3081. PubMed Abstract | Publisher Full Text 


\section{Open Peer Review}

\section{Current Peer Review Status: $\checkmark$ ?}

Version 1

Reviewer Report 31 March 2020

https://doi.org/10.5256/f1000research.24947.r61076

(C) $\mathbf{2 0 2 0}$ Chandler $\mathbf{R}$. This is an open access peer review report distributed under the terms of the Creative Commons Attribution License, which permits unrestricted use, distribution, and reproduction in any medium, provided the original work is properly cited.

\section{Rebecca Chandler \\ Uppsala Monitoring Centre, Uppsala, Sweden}

Causality assessment of adverse events following immunization: the problem of multifactorial pathology.

In his opinion piece the author has addressed the insufficiencies of the WHO AEFI causality algorithm to appreciate the complexities manner in which vaccines cause harm specifically those which are related to an "excessive or biased inflammatory and immune response" to the vaccine product. He writes from the perspective of a pathologist, specialists which are often involved in cases of compensation claims relating to individual level questions of causality. Of particular concern to the author, as demonstrated in the 3 case examples provided, are questions relating to the role of the vaccine as one of potentially multiple factors responsible for the clinical manifestation of an AEFI. In the words of the author: "As far as vaccines are concerned, the fact that severe reactions affect only a few individuals suggests in most cases vaccines are not the only cause of the event and further factors are necessary in the development of pathology". He makes a number of proposals for revisions to the causality algorithm: 1) causality assessment could exclude a consistent association of the adverse event with the vaccine only when the presumed "other cause" is independent of an interaction with the vaccine and 2) the scientific literature should be viewed not as an exclusion criterion but as a comprehensive analysis of all the evidence for or against the role of the vaccine in causing an adverse reaction.

Overall, the opinion of the author is agreed. However, I believe that the manuscript would benefit from some acknowledgement or proposal for revision/clarification of the primary target users of the current WHO AEFI algorithm. The WHO AEFI causality assessment was developed by the Vaccines Safety Group at the WHO with the support of the Global Advisory Committee on Vaccine Safety. The target user group for this classification system are persons working in countries in whom vaccines are administered via WHO sponsored public health programmes (largely LMIC). Those persons are largely concerned with the detection of "signals" of changes in frequency of the more common, expected events which could suggest vaccine quality-related problems, immunisation errors, or multi-use vial contamination, etc. A prioritisation of the identification of such AEFI can be understandable to monitor the safety of vaccines for which there is several years 
of experience and safety surveillance from earlier use in HIC (such as conjugate pneumococcal vaccines, HPV vaccines). Within this framework, the burden of responsibility for surveillance for the rare and unexpected AEFI has fallen to countries (and in fact vaccine manufacturers) with greater resources.

In contrast, higher income countries which do not rely upon implementation of vaccine administration through WHO public health programmes will handle reports of AEFI through these national pharmacovigilance centers. As a result, more general guidance is used for causality assessment, such as the WHO-UMC causality criteria and the Naranjo algorithm which developed by various groups working within the greater field of pharmacovigilance. Within such centers adverse event reports for drugs and vaccines are often maintained within a single database (one notable exception being the USA), and causality assessment is approached in a similar way for all products. Within this arrangement, the surveillance systems are better adapted for the detection of the rare and unexpected.

I would like the author to reflect on the manner in which AEFI reports are handled in Italy, as it would be expected that vaccine reports originating from that country would be subject to collection, analysis and assessment standards endorsed by the European Medicines Agency. With the increasing likelihood of the need to implement new vaccines directly into lower income settings, the requirement of surveillance systems in these countries to detect the "rare and unexpected" is apparent. The author could address this aspect as a way to emphasize the importance of the revisions proposed.

Is the topic of the opinion article discussed accurately in the context of the current literature?

Yes

Are all factual statements correct and adequately supported by citations?

Yes

Are arguments sufficiently supported by evidence from the published literature? Yes

Are the conclusions drawn balanced and justified on the basis of the presented arguments? Partly

Competing Interests: No competing interests were disclosed.

Reviewer Expertise: Pharmacovigilance, vaccine safety surveillance

I confirm that I have read this submission and believe that I have an appropriate level of expertise to confirm that it is of an acceptable scientific standard, however I have significant reservations, as outlined above.

Author Response 02 Apr 2020

Paolo Bellavite, University of Verona School of Medicine, Verona, Italy 
I am glad to see that overall, my opinion is agreed. I thank for the suggestions of the Reviewer and I have revised my paper accordingly. I added two paragraphs to the text of Discussion:

The debate on the best methods of surveillance in the field of vaccinology should remain open, in the interest of the entire population. In the British Medical Journal, dr. Rebecca Chandler has asserted Chandler, 2019 that the target user group for the WHO classification system are persons working in countries in whom vaccines are administered via WHO sponsored public health programmes. Those persons are largely concerned with the detection of "signals" of changes in frequency of the more common, expected events which could suggest vaccine quality-related problems, immunisation errors, or multi-use vial contamination, etc. It seems from this that the WHO causality assessment is meant for poor and developing countries and most reports within the global database for pharmacovigilance have not been subject to WHO AEFI causality assessment. In contrast, higher income countries which do not rely upon implementation of vaccine administration through WHO public health programmes will handle reports of AEFI through these national pharmacovigilance centers. As a result, more general guidance is used for causality assessment, such as the Naranjo algorithm (Naranjo et al., 1981,Belhekar et al., 2014) and the WHO-UMC criteria developed by various groups working within the greater field of pharmacovigilance. The WHO-UMC scale (https://www.who.int/medicines/areas/quality_safety/safety_efficacy/WHOcausality_assessment.pdf) has been developed in consultation with the National Centres participating in the Programme for International Drug Monitoring and is meant as a practical tool for the assessment of case reports. It offers a simple methodology taking into account the clinicalpharmacological aspects of the case history and the quality of the documentation of the observation (Puliyel and Naik, 2018). Within this arrangement, other criteria such as previous knowledge and statistical chance play a less prominent role in the system, so the surveillance systems are better adapted for the detection of the rare and unexpected events.

Despite there is no universally accepted method for causality grading of adverse drug reactions, the WHO algorithm is now recommended specifically for the pharmacovigilance of vaccine adverse events and is increasingly used by researchers and epidemiologists worldwide, in Lower Middle Income Countries like India (Singh et al., 2018; Sebastian et al., 2019) but even in developed countries. For example, the WHO causality assessment guidelines are widely utilized in Italy (Lombardi et al., 2019;Stefanizzi et al., 2019), Germany(Mentzer et al., 2018), Canada (MacDonald and Law, 2017), and were recommended by the Brighton Collaboration Group for analysis of safety data of vaccines in pregnancy (Jones et al., 2016). Given the importance and universal utilization of this approach and its inadequacies in the evaluation of multifactorial diseases, the WHO manual needs to be urgently reevaluated and revised.

\section{References}

Belhekar, M. N., S. R. Taur, and R. P. Munshi, 2014, A study of agreement between the Naranjo algorithm and WHO-UMC criteria for causality assessment of adverse drug reactions: Indian J Pharmacol, v. 46, no. 1, p. 117-120.

Chandler, R. E., 2019, Modernising vaccine surveillance systems to improve detection of rare or poorly defined adverse events: BMJ, v. 365, p. 12268. 
Jones, C. E. et al., 2016, Guideline for collection, analysis and presentation of safety data in clinical trials of vaccines in pregnant women: Vaccine, v. 34, no. 49, p. 5998-6006. Lombardi, N. et al., 2019, Vaccines Safety in Children and in General Population: A Pharmacovigilance Study on Adverse Events Following Anti-Infective Vaccination in Italy: Front Pharmacol, v. 10.

MacDonald, N. E., and B. J. Law, 2017, Le système de innocuité vaccinale canadien en huit étapes : des notions pour les travailleurs de la santé: Paediatr.Child Health, v. 22, no. 4, p. e17-e20.

Mentzer, D., D. Oberle, and B. Keller-Stanislawski, 2018, Adverse events following immunisation with a meningococcal serogroup $B$ vaccine: report from post-marketing surveillance, Germany, 2013 to 2016: Euro.Surveill, v. 23, no. 17.

Naranjo, C. A., U. Busto, E. M. Sellers, P. Sandor, I. Ruiz, E. A. Roberts, E. Janecek, C. Domecq, and D. J. Greenblatt, 1981, A method for estimating the probability of adverse drug reactions: Clin.Pharmacol Ther., v. 30, no. 2, p. 239-245.

Puliyel, J., and P. Naik, 2018, Revised World Health Organization (WHO)'s causality assessment of adverse events following immunization-a critique: F1000Res., v. 7, p. 243. Sebastian, J., P. Gurumurthy, M. D. Ravi, and M. Ramesh, 2019, Active surveillance of adverse events following immunization (AEFI): a prospective 3-year vaccine safety study: Ther.Adv.Vaccines Immunother., v. 7.

Singh, A. K., A. L. Wagner, J. Joshi, B. F. Carlson, S. Aneja, and M. L. Boulton, 2018, Causality assessment of serious and severe adverse events following immunization in India: a 4-year practical experience: Expert.Rev.Vaccines, v. 17, no. 6, p. 555-562.

Stefanizzi, P., P. Stella, D. Ancona, K. N. Malcangi, F. P. Bianchi, N. S. De, D. Ferorelli, C. A. Germinario, and S. Tafuri, 2019, Adverse Events Following Measles-Mumps-Rubella-Varicella Vaccination and the Case of Seizures: A Post Marketing Active Surveillance in Puglia Italian Region, 2017-2018: Vaccines (Basel), v. 7, no. 4.

Competing Interests: I have no competing interests

Reviewer Report 23 March 2020

https://doi.org/10.5256/f1000research.24947.r61079

(C) 2020 Exley C. This is an open access peer review report distributed under the terms of the Creative Commons Attribution License, which permits unrestricted use, distribution, and reproduction in any medium, provided the original work is properly cited.

\section{Christopher Exley}

The Birchall Centre, Lennard-Jones Laboratories, Keele University, Keele, UK

There is one significant omission from this manuscript and it concerns the availability of quality peer reviewed science in the field of AEFI.

How do we know if a vaccine is the origin of AEFI if the vaccine has not been subject to clinical trials involving true placebos. The vehicle for most vaccines, probably all injected vaccines, is $0.9 \%$ 
$\mathrm{NaCl}$. How many vaccine safety trials have used $0.9 \% \mathrm{NaCl}$ as the placebo? The injection of $0.5 \mathrm{~mL}$ of $0.9 \% \mathrm{NaCl}$ IM or SC should be close to being $100 \%$ safe. The needle may damage a capillary and this could produce mild inflammation at the injection site. This could be uncomfortable for a short period of time, there may be some individuals where their genetic make-up means that the discomfort might last a little longer. However, for the vast majority of recipients, $99.9 \%$, the injection of $0.5 \mathrm{~mL}$ of $0.9 \% \mathrm{NaCl}$ is absolutely safe. This is the gold standard placebo against which the safety of all vaccines should be tested and ensured. Of course, the reality is totally different. In my field of interest, vaccines that include an aluminium salt as an adjuvant, there have not been any clinical trials where a vaccine has been tested against a true placebo. I say this with the proviso that in one trial of the HPV vaccine Gardasil there is a report, filed with the Clinical Trials Database, where a small number of trial participants did receive a saline placebo. These individuals reported no (zero) AEFI, while the vaccine group and the Al adjuvant only group reported an incidence of ca $2.5 \% \mathrm{AEFI}$.

The reality is that the design of causality assessment of AEFI is purposely flawed to give both the impression that all vaccines are safe and, of course, to allow those conducting the trials (who are never independent) to decide which of the many and serious AEFI occurring regularly might be attributed to the vaccine. Vaccines are inherently unsafe and rather than investing in improving their safety the industry has devised a mechanism to disguise their toxicity. I do wonder why the author has not included some discussion of this in his otherwise well informed text.

Is the topic of the opinion article discussed accurately in the context of the current literature?

Partly

Are all factual statements correct and adequately supported by citations?

Yes

Are arguments sufficiently supported by evidence from the published literature? Partly

Are the conclusions drawn balanced and justified on the basis of the presented arguments? Partly

Competing Interests: No competing interests were disclosed.

Reviewer Expertise: I work on human exposure to aluminium and this includes an active research programme on the safety of aluminium adjuvants used in vaccinations.

I confirm that I have read this submission and believe that I have an appropriate level of expertise to state that I do not consider it to be of an acceptable scientific standard, for reasons outlined above.

Author Response 02 Apr 2020

Paolo Bellavite, University of Verona School of Medicine, Verona, Italy 
I acknowledge dr. Christopher Exley for his comment, asserting that there is one significant omission from the first edition of the paper, concerning the availability of quality peer reviewed science in the field of AEFI. I agree with his concerns, so I have included a specific paragraph at the end of the Note 3, devoted to the role of medical literature in the overall procedure:

"The WHO manual of causality assessment refers to the peer reviewed literature to evaluate whether there is evidence of association between vaccine and pathology (step 2 of the algorithm) or if there is opposing evidence (step 3). However, this utilization of supposed "evidence" may be flawed, since the safety of vaccines is normally proven with clinical trials that are not conducted by comparisons with a true placebo, such as physiological solution $(0.9 \% \mathrm{NaCl})$. The latter is the "gold standard" placebo against which the safety of all vaccines should be tested and ensured, but the reality is different, especially for those vaccines that contain adjuvants. For example, the safety of the HPV vaccine Gardasil was tested in 6 clinical trials, in 5 of which the control group received Aluminum Hydroxyphosphate Sulfate, while in only one of which the physiological solution was used as placebo. However, in the summary of the safety profile of the vaccine (available from: http://www.merck.com/product/usa/pi_circulars/g/gardasil/gardasil_pi.pdf, accessed 2020 April 2), the systemic and serious adverse effects, namely the rate of autoimmune disorders, are evaluated comparing the group receiving Gardasil with only one group, receiving aluminium or placebo. By this way, any potential reactogenic effect of aluminium salts was masked. Certainly, vaccine safety is assessed also in the post-marketing phase by means of pharmacovigilance systems, which can provide important indications on the incidence of AEFI in vaccinated subjects, which can be compared with unvaccinated subjects. However, this type of comparison is largely subject to various types of selection bias and to the diversity of non-randomized groups. The problem becomes even more serious in the case of adverse reactions with low incidence. For these methodological reasons, the application of the evidence from medical literature to assess causality should be used with great caution and should not become a cut-off argument to establish or exclude causality." I hope thar after this requested implementation, the second version of the manuscript is considered as acceptable.

Competing Interests: I have not competing interests

Reviewer Report 23 March 2020

https://doi.org/10.5256/f1000research.24947.r61073

(C) 2020 Puliyel J. This is an open access peer review report distributed under the terms of the Creative Commons Attribution License, which permits unrestricted use, distribution, and reproduction in any medium, provided the original work is properly cited.

\section{Jacob Puliyel}

Holy Family Hospital, New Delhi, Delhi, India

Paola Bellavite (Verona University, Italy) has reviewed the WHO's causality classification of adverse 
events following immunization (AEFI) in an opinion piece. Using 3 case studies of AEFI deaths reported to the Italian Medicines Agency (Agenzia Italiana del Farmaco AIFA) he illustrates how application of the WHO algorithm is difficult and prone to error.

The glossary of the WHO manual (page vii) defines 'causal association' as a cause and effect relationship between causative factor and a disease with no other factor intervening in the process. Bellavite, quite rightly, feels that this is a wrong approach.

He lists (Table 1), a series of genetic disorders that have been associated with tendency to develop AEFI. Using the WHO definition, a causal association with vaccine would be denied because of the genetic factor intervening in the process. Bellavite has proposed that a 'consistent association of the adverse event with the vaccine' must only be excluded when the presumed 'other cause' independently (without interaction with the vaccine) causes the AEFI. This makes good sense.

At step 3 along the mandatory path of the algorithm, the question is: "Is there strong evidence against a causal association?" Bellavite correctly points out the impossibility of proving a negative. "Lack of evidence of association" may mistakenly be considered as "evidence of lack of association" or evidence against a causal association.

It is interesting that the WHO manual quotes an Institute of Medicine (IOM) report on a study looking at a possible relationship between SIDS and vaccines and which concluded that vaccines did not cause SIDS. Will this loose use of the generic term 'vaccines' mean that, hereinafter, no vaccine can have a causal association with SIDS or does this statement relate only to the vaccines examined by the IOM. The problem with proving a universal negative is that a single instance of a positive association can negate all the previous experiences and studies. Such a universal negative assertion is seldom made in scientific literature.

These are important issues that have been raised.

Till 2013 the WHO used the Brighton classification of AEFI (1) and causal association was classified as 'certain': 'probable': 'possible': 'unlikely' and 'unclassifiable'. The categories were revised in 2013 (2). F1000research published a critique of this classification by the reviewer (3). The Second Edition of Revised AEFI classification was published (with minor changes) in 2018 (4).

In a communication in the British Medical Journal, Chandler of the Brighton Collaboration has asserted (5) and I quote extensively (italicized):

"The WHO AEFI causality assessment was developed by the Vaccines Safety Group at the WHO with the support of the Global Advisory Committee on Vaccine Safety. The target user group for this classification system are persons working in countries in whom vaccines are administered via WHO sponsored public health programmes. Those persons are largely concerned with the detection of "signals" of changes in frequency of the more common, expected events which could suggest vaccine quality-related problems, immunisation errors, or multi-use vial contamination, etc. At the current time, most AEFI reports collected and assessed with the WHO AEFI Causality Classification remain within the databases of the public health programmes and are not forwarded into the databases of the national pharmacovigilance centres of most lower and middle income countries.

In contrast, more general guidance for causality assessment, such as the WHO-UMC causality criteria and the Naranjo algorithm, were developed by various groups working within the greater field of 
pharmacovigilance. The target user groups for these classification systems are those persons working within national pharmacovigilance centres, usually working within or collaboratively with national regulatory centres, and responsible for post-marketing safety surveillance of both drugs and vaccines used within their countries. Within such centres adverse event reports for drugs and vaccines are often maintained within a single database (one notable exception being the USA), and causality assessment is approached in a similar way for all products. Detection of "signals" within the database can be conducted qualitatively (on a "case-by-case" basis) and/or quantitatively (via statistical screening ). Higher income countries which do not rely upon implementation of vaccine administration through WHO public health programmes will handle reports of AEFI through these national pharmacovigilance centres.

Furthermore, it is worth noting that most reports of AEFI contained with Vigibase, the database of individual case safety reports for the WHO Programme of International Drug Monitoring, are from countries who channel reports of AEFI through their national pharmacovigilance system, and therefore most reports within the global database have not been subject to WHO AEFI causality assessment. Taking the specific example of narcolepsy, reports of this condition in association with Pandemrix, an H1N1 pandemic vaccine, were initially received into the national pharmacovigilance centres of Sweden and Finland, and therefore they were not subject to causality assessment by the WHO AEFI classification system. This signal was detected, in fact, because these clusters of reports in young children were "unexpected", by both the reporting physicians (based upon their clinical practice) and by the regulators (based upon the expected reporting patterns within their national databases of suspected adverse drug reactions).

The current system referred to as "robust" within this analysis therefore refers to practice of vaccine pharmacovigilance by national pharmacovigilance/regulatory centres, not that of national immunisation centres routinely utilising the WHO-AEFI causality classification system."

It seems from this that the WHO causality assessment is meant for poor and developing countries and most reports within the global database for pharmacovigilance have not been subject to WHO AEFI causality assessment. it is interesting that the cases cited by Bellavite, the AEFI deaths reported to the Italian Medicines Agency were subjected to the WHO AEFI assessment.

The point that Bellavite makes is that compensation may be denied to families who die after vaccination, utilizing this classification. It will be intriguing to know if this classification is used in Italy to deny compensation but, as a 'developed country', it uses a second system for pharmacovigilance.

The 2018 revised manual says it was 'scientifically evaluated' looking for inter-rater reliability between teams from India and Zimbabwe. It was not examined against any gold standard. If two populations consistently perceive the world is flat, it does little validate the 'scientific' reliability of that perception.

The paper by Bellavite is an important addition to the literature. However, it can be improved by extensive revision. The language can be improved and corrected in many places. This reviewer has often had to resort to such help, for his scientific communications.

1. Introduction: The author writes that AEFI harms a few "unlucky" individuals. The term related to luck put within quotation marks is best deleted in a scientific communication.

2. Page 4 Innate immune response. It is not clear what the author wants to convey about the risk 
of fever after MMR. He says this is more in children under 35 months compared to children older than 4 years of age.

I am not able to understand what this has to do with the AEFI classification and why this is brought up here.

3. Page 5 The author suggests that some autoimmune disorders may be associated with immunization but it is not specified what changes in the AEFI classification will help to identify the role that vaccines play.

4. The list of genetic disorders listed in Table 1 is useful as a ready-reckoner, but for that, it must be as exhaustive as possible. I am not an expert in this area but the association of AEFI with mitochondrial disorders is one that I recognize is missing from the list (Poling PMID 16566887)

5. Page 7 The text says "It is important to point out vaccines may safely be administered in children with Di George syndrome."

Why is it important to state this? There are a whole host of genetic disorders where vaccines can be administered with impunity. Why has Di Gorge been singled out to be declared as safe

6. Micrbiome - The relevance of the paragraph on the microbiome is also not clear in the context of AEFI classification.

7. Page 8 The first two paragraphs: It is not clear what the author wants to convey and how it relates to the WHO AEFI classification method

8. Page 9 Top paragraph not clear

9. So also Note 3 The Literature (Delete 'Note 3' from the paragraph heading)

The content of this paragraph is not clear

10. Page 10 Second last paragraph

The author writes

"The most obvious case of a possible overlap between autism spectrum symptoms and another disease, surely caused by vaccine adjuvants, is the macrophagic myofasciitis."

A little more elaboration would be helpful because macrophagic myofasciitis is a relatively new syndrome associated with vaccine aluminium adjutants and its association with cognitive disorders is known even less.

\section{References}

1. WHO: Adverse Events Following Immunization(AEFI): Causality Assessment. 2005. Reference Source

2. WHO: Causality assessment of an adverse event following immunization (AEFI). 2018. Reference Source

3. Puliyel J, Naik P: Revised World Health Organization (WHO)'s causality assessment of adverse events following immunization-a critique.F1000Res. 2018; 7: 243 PubMed Abstract | Publisher Full Text 
4. Chandler R: Modernising vaccine surveillance systems to improve detection of rare or poorly defined adverse events. BMJ. 2019. Publisher Full Text

Is the topic of the opinion article discussed accurately in the context of the current literature?

Partly

Are all factual statements correct and adequately supported by citations? Partly

Are arguments sufficiently supported by evidence from the published literature? Partly

Are the conclusions drawn balanced and justified on the basis of the presented arguments? Partly

Competing Interests: No competing interests were disclosed.

Reviewer Expertise: Pediatrics

I confirm that I have read this submission and believe that I have an appropriate level of expertise to confirm that it is of an acceptable scientific standard, however I have significant reservations, as outlined above.

Author Response 02 Apr 2020

Paolo Bellavite, University of Verona School of Medicine, Verona, Italy

I thank Dr. Puliyel for his reviewer's report that allows me to improve the paper and specify some aspects better. Here I respond to his observations point-by-point and highlight the new parts inserted in the text

I appreciate that the most important proposal of the paper has been accepted. Rightly dr. Pulijel recalls that the same F1000research Journal published a critique of this classification, which I appropriately cited (quotation 158 of the first version). There are several points raised by the Reviewer that I have addressed in the revised paper:

1. Dr. Puliyel has cited a long and interesting declaration of $\mathrm{dr}$. Chandler including the sentence "The target user group for this classification system are persons working in countries in whom vaccines are administered via WHO sponsored public health programmes " and suggested that "It seems from this that the WHO causality assessment is meant for poor and developing countries and most reports within the global database for pharmacovigilance have not been subject to WHO AEFI causality assessment. it is interesting that the cases cited by Bellavite, the AEFI deaths reported to the Italian Medicines Agency were subjected to the WHO AEFI assessment."

Response: This is a straightforward point that was raised also by dr. Chandler as Reviewer and I have modified the text according your and her suggestions. I have given only one response, under her comments to the paper. Moreover, connected with Chandler's comments, I have added to the Discussion a paragraph to better clarify the limitations of 
WHO algorithm for evaluating the responsibility of vaccines in multifactorial AEFI: "The WHO causality assessment is mainly constructed on a concept of direct 'a cause-and-effect relationship", thus dismissing the multifactorial nature of inflammatory and immune phenomena. By underestimating interacting causes, the method classifies a possible association as "inconsistent" when there is another cause and as "indeterminate" when the role of the vaccine can't be excluded, but there is no proof that it is "the" cause. Using this definition of causal association, many adverse events, where the vaccine plays a role as concause, remain unrecognized. Others (Puliyel and Naik, 2018) have noted that, according to this scheme, an acute cardiac decompensation after influenza vaccination in an elderly person with chronic cardiac failure might not be considered as causally related to the vaccine. Similarly, sudden death after vaccination of an infant with pre-existing heart disease might not have relationship with the vaccine. Furthermore, the contribution of vaccine in precipitating encephalopathy in patients who are susceptible on account of genetic factors will also not be considered. If this type of problem occurs, in addition to causing detriment to a injured person, it leads to an overall underestimation of the risks of a given vaccine.

2. The point that Bellavite makes is that compensation may be denied to families who die after vaccination, utilizing this classification. It will be intriguing to know if this classification is used in Italy to deny compensation but, as a 'developed country', it uses a second system for pharmacovigilance.

Response: In Italy, the WHO classification is considered the "gold standard" in the evaluation of AEFI originating from pharmacovigilance reports, so it is normally the only one that is used for causality assessment. Of course, if people who believe they have suffered unrecognized damage from vaccination appeal to a court of justice, a much more detailed assessment follows, where the expert consultants of the parties are challenged with all the available documentation. I have added this further explanation to the Discussion in the paragraphs concerning the compensation.

3. The 2018 revised manual says it was 'scientifically evaluated' looking for inter-rater reliability between teams from India and Zimbabwe. It was not examined against any gold standard. If two populations consistently perceive the world is flat, it does little validate the 'scientific' reliability of that perception.

Response: I agree that this is one of the several problems raised by the manual and I hope that my paper will contribute to highlight that considering the WHO classification as an universal "gold standard" would be an error.

4. Introduction: The author writes that AEFI harms a few "unlucky" individuals. The term related to luck put within quotation marks is best deleted in a scientific communication Response: OK I agree and have removed this word

5. Page 4 Innate immune response. It is not clear what the author wants to convey about the risk of fever after MMR. He says this is more in children under 35 months compared to children older than 4 years of age. I am not able to understand what this has to do with the AEFI classification and why this is brought up here.

Response: I wanted to report in one sentence the quantitative value of the risk of febrile seizures according to the literature and in the following one the risk of MMRV compared to MMR alone. I believe it is important to offer readers an estimate of what the frequency of one of the most serious adverse reactions is, because the evaluation of causality must also take into account, among the other factors, also the probability that a certain AEFI can occur 
in a specific age group.

6. Page 5 The author suggests that some autoimmune disorders may be associated with immunization but it is not specified what changes in the AEFI classification will help to identify the role that vaccines play.

Response: This topic is very important but does not have an easy solution. In fact, as has been reported in the text, autoimmune diseases and in general chronic post-vaccination chronic syndromes are due to multiple factors intertwined with each other and, moreover, they can arise weeks or months after vaccination. However, to answer the reviewer's correct question, I have added a paragraph on autoimmune diseases to the "final categorization" in Discussion (Note 4.) and on page 5 I have added a sentence that refers to the final discussion: "The implications of these concepts in the causality assessment are discussed in a later chapter (see Note 4.)" The added paragraph is the following: "As mentioned, multifactorial diseases, such as autoimmune diseases, are often conditioned by various genetic and acquired factors. In these cases, the role of vaccination could be to slatentize a predisposing condition, which would have led to the disease slower or would not even appear. If this is the case, it is probable that the case study will neither confirm nor deny the role of the vaccine, so that the causality assessment would come to the conclusion of an "undetermined" association. Obviously, this procedure, if applied systematically to a series of cases, would lead to an underestimation of the etiological role of vaccines in autoimmune diseases. To overcome this vicious circle, in the final categorization (phase IV), the probability that the vaccine played a role in determining the event could be assessed and scored, taking into account the other possible factors involved. In this way, it would prevent information on the partial role of the vaccine, obtained from a particular case, from being lost in the study of a series of cases."

7. The list of genetic disorders listed in Table 1 is useful as a ready-reckoner, but for that, it must be as exhaustive as possible. I am not an expert in this area but the association of AEFI with mitochondrial disorders is one that I recognize is missing from the list (Poling et al., 2006)

Response: I thank of this suggestion, I have added the indicated reference to Table 1 . To the best of my knowledge, there are not further genetic traits which have been associated with AEFI.

8. Page 7 The text says "It is important to point out vaccines may safely be administered in children with Di George syndrome." Why is it important to state this? There are a whole host of genetic disorders where vaccines can be administered with impunity. Why has Di Gorge been singled out to be declared as safe Response. Also this question is correct. The reason is that this is a genetic disorder of immune system (immunodeficiency), it is a notable exception of the rule that live vaccinas should not be administered to these children. In any case, to better clarify this point, in the revised version I have changed "in this context" (too generic) to "in the context of immunodeficiency diseases"

9. Microbiome - The relevance of the paragraph on the microbiome is also not clear in the context of AEFI classification.

Response: Indeed, this point needs to be clarified. Thanks to the reviewer's question, I added this explanation at the end of the microbiome paragraph: "The role of microbiome is important from the perspective of susceptibility factors of AEFI, because it is possible that an alteration of the gut health, especially with the leak of endotoxins in the general circulation, increases the susceptibility to a stronger and more serious reaction to the 
immune stimulus represented by the vaccine. Under these predisposing conditions the plausibility that a serious inflammatory reaction may be triggered by a vaccination increases."

10. Page 8 The first two paragraphs: It is not clear what the author wants to convey and how it relates to the WHO AEFI classification method

$\mathrm{R}$ : This topic is central and has to do precisely with the complex nature of many reactions to vaccines. Also thanks to the review to the first version by Dr. David Legge, who appreciated the setting of the entire work based on the description of the typical features of complex systems, I believe that this difficult topic has been well developed. Since it is possible that the meaning of this point may still be a little obscure, I added an explanatory paragraph, which is more closely related to the AEFI causal assessment: "Therefore, in the case of diseases involving several possible causes and/or mechanisms, the purpose of AEFI classification cannot be to identify "the" determining cause, but it may be more correct to try to establish with what probability one or more the factors involved (vaccines, genetic or epigenetic traits, previous or concomitant infections, drugs, age, gender, nutrition and metabolism, etc.) may have contributed to the occurrence of the event. "

11. 8. Page 9 Top paragraph not clear

Response. I have added a further paragraph to better clarify the problem of time window: "The WHO guidelines consider this problem under the question "In this patient, did the event occur within a plausible time window after vaccine administration?" and in a note cite as a "detailed document" a book of the Institute of Medicine(Institute of Medicine, 2012). However, in that document there are no indications on the suitable time windows of autoimmune diseases or in general of chronic diseases following vaccinations. In some cases, causality is excluded by using rather short time windows. For example, the case of a man with symptoms of chronic inflammatory disseminated polyneuropathy that occurred 8 weeks after a tetanus toxoid vaccine(Hughes et al., 1996) is presented and it is argued that this interval is "too long". However, autoimmune diseases and chronic post-vaccination syndromes in general can occur several weeks or months after vaccination. In cases of fibromyalgia and chronic fatigue disease following hepatitis B vaccination (Agmon-Levin et al., 2014), the time interval between vaccination and the onset of symptoms was 38.6 days, but with a large time interval (+/- 79.4 days). In a systematic prospective case-referent study conducted to assess the risks of autoimmunity associated with HPV vaccines, a reasonable time window of 24 months for multiple sclerosis, connective tissue disease, type-1 diabetes, and thyroiditis was adopted (Grimaldi-Bensouda et al., 2017). This paper excluded an association between HPV vaccination and these disease, but an increased percentage of cases had personal or family (in first-degree relatives) history of autoimmunity $(14.7 \%$ of cases versus $7.2 \%$ of referent group, $p<0.05$ ), endorsing the importance of genetic susceptibility to vaccine adverse effects. Given the complexity and multifactoriality of chronic autoimmune diseases and the lack of precise references on the time frame of appearance of these diseases after vaccination, the possibility could be considered that, in an upcoming edition of the guidelines, it is specified that the time window for autoimmune diseases should be sufficiently large (e.g. 24 months(Grimaldi-Bensouda et al., 2017) ) to not exclude slow-onset cases, or that a restricted time frame should be applied only to AEFI with acute onset (for example: hyperthermia, febrile seizures, anaphylaxis).

12. So also Note 3 The Literature (Delete 'Note 3' from the paragraph heading) The content of this paragraph is not clear

Response: To clarify the meaning of the paragraph, at the beginning I have added a 
sentence: " In practice, if there is published evidence in literature that rejects a statistically significant association between a disease and previous vaccinations, this argument could be used to exclude in each particular case that vaccination may have caused the reported disease. The evidence at population scale is used at individual level." I cannot delete the words "Note 3 " because the heading helps to clarify that this paragraph connects with the third step of the algorithm and the whole chapter is divided into four notes in their order. 13. Page 10 Second last paragraph. The author writes "The most obvious case of a possible overlap between autism spectrum symptoms and another disease, surely caused by vaccine adjuvants, is the macrophagic myofasciitis." A little more elaboration would be helpful because macrophagic myofasciitis is a relatively new syndrome associated with vaccine aluminium adjuvants and its association with cognitive disorders is known even less.

Response: This topic was developed in a previous chapter, where the pathogenic effects of aluminum on the central nervous system were described, including cognitive dysfunction, sensory disturbances, and motor retardation. I added this sentence to the discussion at that point mentioned by the Reviewer.

I believe these changes help make the text clearer and I thank the Reviewer for that

Reference List

Agmon-Levin N, Zafrir Y, Kivity S, Balofsky A, Amital H, Shoenfeld Y. Chronic fatigue syndrome and fibromyalgia following immunization with the hepatitis $B$ vaccine: another angle of the 'autoimmune (auto-inflammatory) syndrome induced by adjuvants' (ASIA). Immunol Res 2014; 60(2-3): 376-383.

Grimaldi-Bensouda L, Rossignol M, Kone-Paut I, Krivitzky A, Lebrun-Frenay C, Clet J, Brassat D, Papeix C, Nicolino M, Benhamou P Y, Fain O, Costedoat-Chalumeau N, Courcoux M F, Viallard J F, Godeau B, Papo T, Vermersch P, Bourgault-Villada I, Breart G, Abenhaim L. Risk of autoimmune diseases and human papilloma virus (HPV) vaccines: Six years of casereferent surveillance. J Autoimmun 2017; 79: 84-90.

Hughes R A, Choudhary P P, Osborn M, Rees J H, Sanders E A. Immunization and risk of relapse of Guillain-Barre syndrome or chronic inflammatory demyelinating polyradiculoneuropathy. Muscle Nerve 1996; 19(9): 1230-1231.

Institute of Medicine. Adverse effects of vaccines: Evidence and causality. The National Academies Press, Washington, DC 2012.

Poling J S, Frye R E, Shoffner J, Zimmerman A W. Developmental regression and mitochondrial dysfunction in a child with autism. J Child Neurol 2006; 21(2): 170-172. Puliyel J, Naik P. Revised World Health Organization (WHO)'s causality assessment of adverse events following immunization-a critique. F1000Res 2018; 7: 243.

Competing Interests: I have no competing interests 
(c) 2020 Legge $\mathbf{D}$. This is an open access peer review report distributed under the terms of the Creative Commons Attribution License, which permits unrestricted use, distribution, and reproduction in any medium, provided the original work is properly cited.

\section{David Legge}

School of Public Health, La Trobe University, Melbourne, Vic, Australia

The author suggests that the 2018 WHO algorithm for causality assessment in cases of adverse events following immunisation (AEFI) may be overly mechanistic and may not do justice to the complexity of biological systems and the possibility of multifactorial causation.

He sets the scene regarding bio-complexity with reference to complex disease causation, the complexity of the immune response (including the genesis of autoimmunity), the role of genetic variants in modulating immune reactions, and the role of the microbiome.

He then examines the $2018 \mathrm{WHO}$ algorithm considering four steps in some detail.

The first step in WHO's causal algorithm asks if there is 'strong' evidence for an alternative cause of the event. The author suggests that this either-or question precludes consideration of the possibility of an interaction between the alternative cause and the immunisation event.

The second question raised concerns the significance of temporal association (between immunisation and adverse event) in determining causality. The author argues, drawing particularly on immunopathology, that some pathways of causation could operate over weeks and months rather than hours and days.

The third element of the algorithm which the author questions concerns the exclusion (with respect to causality) of cases where there is 'strong' evidence against a causal relation. The concern raised here concerns the meaning of 'strong' evidence in relation to the methodological limitations of such research.

The fourth element of the algorithm in question concerns the final classification of 'consistent with' or 'not consistent with' causality. Here the author returns to his concerns about the either-or logic upon which the algorithm rests and the need to properly accommodate multifactorial causation.

In concluding his review the author proposes further development of the WHO algorithm to better accommodate multifactorial causation. He also comments on the links between AEFI causality assessment and access to compensation for people who have experienced harm after immunisation. He suggests that the appropriate standards for causal inference for compensation purposes might not be same as those for regulatory purposes. Finally the author returns to multifactorial causation, highlighting in particular, genetic influences and the need for further research including regulatory monitoring of genetic factors (and perhaps microbiomic factors). He suggests that closer attention to the interplay of these (potentially) contributory factors could contribute to more evidence-informed decision-making regarding exemptions from mandated (or highly recommended) immunisations.

This is a very thoughtful and well informed contribution to the continuing discussion of causal 
assessment in cases of AEFI. The author has presented a 'strong' case for closer attention to complexity and multifactorial causation in causality assessment of AEFIs. The distinctions he makes between the different contexts and purposes of causal assessment (regulation, compensation and exemption) are useful.

Is the topic of the opinion article discussed accurately in the context of the current literature?

Yes

Are all factual statements correct and adequately supported by citations? Yes

Are arguments sufficiently supported by evidence from the published literature? Yes

Are the conclusions drawn balanced and justified on the basis of the presented arguments? Yes

Competing Interests: No competing interests were disclosed.

Reviewer Expertise: I am a generalist public health physician with a particular interest in global health policy. I have a long standing interest in complexity theory as applied to biological and social systems. However, I have approached this review with a policy perspective.

I confirm that I have read this submission and believe that I have an appropriate level of expertise to confirm that it is of an acceptable scientific standard.

Author Response 30 Mar 2020

Paolo Bellavite, University of Verona School of Medicine, Verona, Italy

I warmly thank Doctor Legge for this positive comment on my work, of which he demonstrates that he has understood the fundamental meaning in the context of the complex vision of multifactorial diseases. His contribution is invaluable in preparing the second version and I will certainly take it into account Paolo Bellavite (Author)

Competing Interests: No competing interests were disclosed. 
The benefits of publishing with F1000Research:

- Your article is published within days, with no editorial bias

- You can publish traditional articles, null/negative results, case reports, data notes and more

- The peer review process is transparent and collaborative

- Your article is indexed in PubMed after passing peer review

- Dedicated customer support at every stage

For pre-submission enquiries, contact research@f1000.com 